\title{
How diabolic is the sovereign-bank loop? The effects of post-default fiscal policies*
}

\author{
André Diniz ${ }^{\dagger} \quad$ Bernardo Guimaraes ${ }^{\ddagger}$
}

January 2017

\begin{abstract}
The deleterious effect of debt restructuring on banks' balance sheets and, consequently, on the economy as a whole has been a key policy issue. This paper studies how post-default fiscal policy interacts with this sovereign-bank loop and shape the response of a model economy. Calibration of the model matches characteristics of the Greek economy at the time of the Bond Exchange. Debt restructuring in place of higher lump-sum taxation or non-productive government spending harms the economy even if no other cost of default is considered. However, the sovereign-debt loop is less costly to the economy than increases in labour or capital taxes to service debt. Even so, if fiscal policy is too responsive, a crowding-out effect inhibits the recovery of capital markets, hence a more conservative fiscal stance is desirable. Thus how diabolic the post-default sovereign-bank loop is depends to a large extent on the way fiscal policy responds.
\end{abstract}

KEYWORDS: financial frictions, fiscal policy, sovereign default, sovereign-bank loop.

Jel Classification: E32, E62, F34, G01, H63.

\section{Introduction}

In policy discussions about the debt crisis in the Euro area, one key issue has been the deleterious effect of sovereign debt restructuring on bank's balance sheets and, consequently, on the economy as a whole. The mechanism runs as follows: sovereign debt restructuring leads to lower prices for sovereign debt, and thus implies a reduction in the value of banks' assets. This in turn forces banks to deleverage, reducing credit in the economy and leading to a sharp fall in economic activity. In consequence, tax revenues

\footnotetext{
*We thank Luis Araujo, Chryssi Giannitsarou, Carlos Eduardo Gonçalves, Ricardo Reis, Pontus Rendahl, Marcel Ribeiro, Vladimir Teles, and seminar participants at Banco Central do Brasil, U Cambridge, Econometric Society NASM 2014 (Minneapolis), ESEM 2014 (Toulouse), LAMES 2014 (Sao Paulo), RIDGE 2015 (Montevideo), SBE 2014 (Natal) and Sao Paulo School of Economics - FGV for useful comments. This paper subsumes the material in "Financial disruption as a cost of sovereign default: a quantitative assessment". Diniz gratefully acknowledges financial support from FAPESP. Guimaraes gratefully acknowledges financial support from CNPq.

${ }^{\dagger}$ Sao Paulo School of Economics - FGV.

${ }_{\ddagger}^{\ddagger}$ Sao Paulo School of Economics - FGV.
} 
fall. A recent literature has evolved to assess the importance of this sovereign-bank loop - the so called diabolic loop. ${ }^{1}$

However, sovereign default is effectively a transfer from debt holders to the government, not a destruction of wealth. Hence, on the one hand, a default episode tightens the constraints on banks and forces them to deleverage, which leads to lower investment and lower output. But on the other hand, it loosens the government's budget constraint since, presumably, servicing debt would require higher taxes or less government spending. Therefore, one of the main factors dictating what then happens to the economy is the fiscal response after default.

This paper studies how different fiscal policy responses affect the sovereign-bank loop in a quantitative macroeconomic model. Banks are leverage-constrained as in Gertler and Kiyotaki (2010) and Gertler and Karadi (2011) and hold sovereign bonds. ${ }^{2}$ Several fiscal policy instruments are considered: government purchases; lump sum taxes; taxes on labour; taxes on capital income; taxes on banks; and taxes on consumption. The model portrays a closed economy and abstracts from nominal rigidities and monetary policy. Compared to models with an endogenous default decision, ours is simpler, but also easier to quantify and, in this sense, more transparent.

The model is calibrated to capture the sovereign-bank loop in the Greek economy following the 2012 Bond Exchange. We consider a counterfactual steady state with no default and simulate an exogenous debt restructuring episode, modeled as a sharp fall in current debt payments that phases out over time. We study how the reaction of the economy to the debt restructuring shock depends on the fiscal policy response.

Debt restructuring in place of higher lump-sum taxation leads to a very persistent but mild output drop. Even though no other cost of default is considered, the restructuring shock leads to a fall in economic activity owing to its effects on banks' balance sheets, since banks are forced to deleverage. Moreover, restructuring debt instead of cutting government consumption leads to a larger fall in investment and output. Intuitively, the increase in government consumption following default crowds out investment, aggravating the diabolic loop.

However, when distortionary taxation is considered, results are very different. We first consider a tax on labour income. While debt restructuring forces banks to deleverage, it also avoids an increase in taxes that would lead to a reduction in labour supply. In our

\footnotetext{
${ }^{1}$ Examples include Acharya, Drechsler and Schnabl (2015), Bocola (2016), Broner et al (2014), Brunnermeier et al (2016), Brunnermeier et al (2017), Perez (2015) and Sosa-Padilla (2015).

${ }^{2} \mathrm{~A}$ recent empirical literature highlights the importance of banks' holdings of government debt. See, e.g, Bank of International Settlements (2011), Andritzky (2012), De Bruyckere et al (2013), Gennaioli, Martin and Rossi (2013) and Popov and Van Horen (2014).
} 
laboratory economy, this effect on labour supply is the dominating force and brings a halt to the diabolic sovereign-bank loop.

In the case of consumption taxes, the response of the economy in the short run is very similar to the case of labour taxes, but since lower consumption taxes also crowd out investment, after a few years, output is below its level in case of no default.

When sovereign debt restructuring occurs in place of increases in taxes on capital income or banks' profits, the effect on investment is positive. Intuitively, default is a one-off transfer from banks to the government, but so are taxes on banks and the latter also affect marginal lending decisions. Owing to these positive effects on bank credit, sovereign debt restructuring is less harmful than an increase in taxes on capital income or on banks. The effect is particularly strong in the medium and long run - the output response peaks only after 5 years.

We then let fiscal policy react to a greater extent to default, so taxes decrease more, but debt recovers faster. This has a positive effect on output in the short run. However, sovereign debt issuance crowds out space for capital investment in banks' balance sheets, and a more expansionary fiscal policy exacerbates this effect. In consequence, the overall impact on the economy of a more expansionary fiscal stance is negative.

In sum, in our laboratory economy, the type of fiscal instrument and the speed of adjustment interact with the financial disruption caused by debt restructuring. As it turns out, this interaction is very important to determine how the economy responds.

This paper is organized as follows: the next subsection connects our contribution to the literature. Section 2 presents the model, section 3 briefly describes the Greek Debt Restructuring from 2012, explains how we calibrate the model and details the simulation exercise. Results are presented in section 4 and section 5 concludes.

\subsection{Related Literature}

Our paper speaks to a growing literature on the financial disruption triggered by sovereign default. This literature studies the so-called sovereign-bank (diabolic) loop: when leveragedconstrained banks hold large amounts of domestic sovereign debt, default (or an increase in default risk) leads to less credit, lower output and tax revenues, generating a feedback loop that further worsens the government's repayment capacity.

Sosa-Padilla (2015) extends a standard quantitative sovereign default model to endogenize the output costs of default via credit crunch and calibrates the model to match the Argentinian default. Bocola (2016) models two channels through which this loop can be provoked. In addition to the common liquidity channel, also present in this paper and 
many others, he shows that news about sovereign risk generate a precautionary motive for banks to deleverage (the "risk channel"). Perez (2015) stresses the relevance of the liquidity value of public debt for banks and studies the effects of post-default bail-outs. Broner et al (2014) analyse creditor discrimination in the presence of secondary markets. Their model highlights the crowding-out effect present in this paper: public credit displaces credit for productive investment. Brunnermeier et al (2016) and Brunnermeier et al (2017) propose a way to break the feedback mechanisms that perpetuate the loop. They argue that changes in sovereign bonds' prices would be almost completely smoothed out by imposing banks to hold a quasi risk-free asset consisting of a diversified portfolio with senior tranches of government debt.

While most of the literature explicitly models the government's decision about defaulting or not, we model sovereign debt restructuring as an exogenous policy shock. Despite this simplification, our model is able to capture the liquidity effects resulting from default and also generates the crowding-out effect that is key in these models. We contribute to the literature by studying how this sovereign-bank loop is affected by the use of different fiscal policy instruments and the speed of fiscal policy response.

The nature of losses from sovereign default is a question that dates back to Eaton and Gersovitz (1981) and Bulow and Rogoff (1989). In a survey of this literature, Panizza, Zettelmeyer and Sturzenegger (2009) argue that there is not much evidence that external penalties are the main reason why governments repay their debts and highlight the importance of domestic costs following defaults. Indeed, a recent literature on debt crises has aimed at exploring the channels through which default can trigger domestic output costs. A branch of this literature has turned its attention to the link between sovereign default and liquidity crises. ${ }^{3}$ Our results, however, raise question marks about the magnitude of these costs.

Empirical work has explored this link between sovereign risk and banks' financing conditions. Borensztein and Panizza (2008) show empirical evidence that default episodes tend to magnify the probability of banking crises and domestic credit crunches, associated with balance sheet effects and collapses in confidence. Andritzky (2012) points out that the subprime crisis has affected the investor base for government securities in some advanced G20 economies. Following the European debt crisis, Bank of International Settlements (2011) highlighted that the increase in sovereign risk could affect the market value of banks through their holdings of sovereign debt. Gennaioli, Martin and Rossi (2013) provide evidence that sovereign bonds generate a liquidity benefit for banks in

\footnotetext{
${ }^{3}$ See, e.g., Brutti (2011) and Broner and Ventura (2011).
} 
normal times, but are costly during debt crises. ${ }^{4}$

The model also builds on the literature about the role of financial frictions in business cycles and the so called "financial accelerator" channel. Many of the main contributions to this literature introduce financial frictions as an agency problem. ${ }^{5}$ We closely follow the modeling of financial frictions from Gertler and Kiyotaki (2010) and Gertler and Karadi (2011). ${ }^{6}$ Gertler and Karadi (2011) and Gertler, Kiyotaki and Queralto (2012) study the recent financial crisis and the effects of unconventional monetary policy using a financial accelerator model where banks face a no-moral-hazard constraint that limits their ability to raise funds. As in other models in this literature, these frictions amplify the effects of exogenous shocks to business cycles. ${ }^{7}$ Building on this framework, Kirchner and Van Wijnbergen (2016) investigate fiscal policy efectiveness during a crisis when private sector and government compete for credit from leverage-constrained banks. They show that fiscal policy is less effective if debt cannot be directly held by households, causing a crowding-out effect in credit provision.

There is also recent research investigating the links between sovereign risk and macroeconomic stability. Corsetti et al (2013) and Corsetti el al (2014) develop macroeconomic models with financial frictions using Curdia and Woodford's (2016) framework, but they assume an exogenous connection between sovereign risk and banks' spreads (loan over deposit rates). Here, this connection is endogenous and crucial for our analysis. Bolton and Jeanne (2011) analyse theoretically the consequences of debt crises in a financially integrated world, where a sovereign country's debt can be used as collateral by banks in other countries. Guerrieri, Iacoviello and Minetti (2012) analyse the international transmission of sovereign risk and default in the Eurozone through the banks' balance sheet channel and show that default in the so called "periphery countries" spreads to banks at the core.

\footnotetext{
${ }^{4}$ See also De Bruyckere et al (2013) and Popov and Van Horen (2014).

${ }^{5}$ See, e.g., Bernanke and Gertler (1989), Carlstrom and Fuerst (1997), Kiyotaki and Moore (1997) and Bernanke, Gertler and Gilchrist (1999).

${ }^{6}$ This framework has been used and extended in several directions. Examples include Villa and Yang (2011), Gertler, Kiyotaki and Queralto (2012), Dedola, Karadi and Lombardo (2013), Gertler and Karadi (2013), Correia et al (2015), Meeks, Nelson and Alessandri (2016), Rannenberg (2016) and Villa (2016).

${ }^{7}$ Boissay, Collard and Smets (2016) expand the financial accelerator framework and are able to generate credit freezes and banking crises as a result of endogenous pro-cyclical movements in banks' balance sheets.
} 


\section{Model}

Our stochastic general equilibrium model is composed of a closed real economy and abstracts from nominal rigidities and monetary policy. ${ }^{8}$ The model considers a government that issues non-state contingent debt (that can be defaulted on) and a variety of fiscal policy instruments. The modeling of financial frictions follows Gertler and Kiyotaki (2010) and Gertler and Karadi (2011). The economy is populated by five types of agents: households, good producers, capital producers, bankers and government.

\subsection{Households}

There is a representative household with a continuum of members of measure unity, with a fraction $1-f$ that are workers and a fraction $f$ that are bankers. Workers supply labour and return wages to the family, while bankers own a financial intermediary and return dividends to their household. Households can save in form of deposits held by intermediaries. They supply funds to banks in form of non-contingent short term debt (deposits, denoted $D_{t}$ ), that pay a risk-free gross real return rate $R_{t}$. We additionally assume households can not buy government bonds directly.

Households choose consumption $\left(C_{t}\right)$, labour supply $\left(L_{t}\right)$ and riskless debt to maximize expected discounted utility. We assume preferences in logaritmic form that follow a $\mathrm{GHH}$ specification, in order to avoid the wealth effects on labour supply (Greenwood, Hercowitz and Huffman, 1988) ${ }^{9}$.

$$
E_{t} \sum_{i=0}^{\infty} \beta^{i} \log \left[C_{t+i}-\frac{\psi}{1+\varphi} L_{t+i}^{1+\varphi}\right]
$$

Households are subject to the following budget constraint:

$$
\left(1+\tau_{t}^{c}\right) C_{t}+\left(D_{t+1}-D_{t}\right)=\left(1-\tau_{t}^{w}\right) W_{t} L_{t}+\left(R_{t}-1\right)\left(1-\tau_{t}^{d}\right) D_{t}+\Pi_{t}-T R_{t}
$$

where $W_{t}$ is the wage rate, $T R_{t}$ are lump-sum tranfers payed (received) to the government and $\Pi_{t}$ are the dividends obtained from the ownership of nonfinancial firms and banks. Tax rates are also indexed to $t$. Taxation is composed by consumption taxes $\left(\tau_{t}^{c}\right)$ and income taxes of two forms: taxes on wages $\left(\tau_{t}^{w}\right)$ and taxes on (net) returns of savings $\left(\tau_{t}^{d}\right)$.

\footnotetext{
${ }^{8}$ Differently from the literature on sovereign default that builds on Eaton and Gersovitz (1981), our model does not portrait an open economy. Our focus is instead on the debt being held by domestic banks. We are hence abstracting from other channels through which default may harm the economy, such as external sanctions, fall in international trade and drops in foreign direct investment.

${ }^{9}$ In the sensitivity analysis we allow alternatively for preferences following King, Plosser and Rebelo (1988) and show that conclusions are not driven by the assumption on the form of the utility function.
} 
From the first order conditions for consumption/saving, we get:

$$
E_{t} \beta \Lambda_{t, t+1}\left[\left(1-\tau_{t+1}^{d}\right)\left(R_{t+1}-1\right)+1\right]=1
$$

where $\Lambda_{t, t+1}$ is the households' stochastic discount factor:

$$
\Lambda_{t, t+1} \equiv \frac{\varrho_{t+1}}{\varrho_{t}} \frac{\left(1+\tau_{t}^{c}\right)}{\left(1+\tau_{t+1}^{c}\right)}
$$

and $\varrho_{t}$ is marginal utility of consumption,

$$
\varrho_{t} \equiv\left(C_{t}-\frac{\psi}{1+\varphi} L_{t}^{1+\varphi}\right)^{-1}
$$

The first order condition for labour supply writes:

$$
\psi L_{t}^{\varphi}=\frac{\left(1-\tau_{t}^{w}\right) W_{t}}{\left(1+\tau_{t}^{c}\right)}
$$

In every period, there is a probability $(1-\theta)$ that a banker becomes a worker. In order to maintain the fraction in each occupation constant over time, in each period there is a random fraction $(1-\theta) f$ of workers that become bankers. Workers that become bankers receive a "start up" capital from the household to start business. Expected survival time of a bank is thus $1 /(1-\theta)$. This prevents bankers from accumulating enough wealth so as to overcome their financial constraints.

Households also own nonfinancial firms (capital and goods producers). However, they are not able to acquire capital directly or to provide funds to these firms. All financial intermediation for production must be made by a bank.

\subsection{Goods producers}

The representative firm in this sector produces output in a competitive market, using labour and capital in a Cobb-Douglas technology:

$$
Y_{t}=K_{t}^{\alpha} L_{t}^{1-\alpha}
$$

with $0<\alpha<1$.

As usual, labour demand implies that the real wage rate equals the marginal product of labour:

$$
W_{t}=(1-\alpha) \frac{Y_{t}}{L_{t}}
$$

In order to produce in period $t+1$, firms need to buy the amount of capital $K_{t+1}$ at the end of period $t$ from capital producers. In order to finance the acquisition of capital, firms 
issue securities $S_{t}$ and an arbitrage condition ensures the value of these securities equals the value of the capital to be bought. The intermediaries buy these securities. Denoting by $Q_{t}$ the price of one unit of capital, we have:

$$
Q_{t} K_{t+1}=Q_{t} S_{t}
$$

There are no frictions in this process. Intermediaries have perfect information about the firm and about future payoffs, so securities are state-contingent. Frictions exist within the process of banks obtaining resources from households.

In order to satisfy the zero profit condition in the competitive market, goods producers buy capital goods up to the point that gross profits per unit of capital $Z_{t}$ equal the marginal product of this input:

$$
Z_{t}=\frac{Y_{t}-W_{t} L_{t}}{K_{t}}=\alpha \frac{Y_{t}}{K_{t}}
$$

A firm that sells $S_{t}$ securities to acquire capital must return all its profits in the next period to the bank. Call $R_{k t}$ the gross return to capital in time $t$, the amount a bank obtains as a return over each unit of credit supplied in the form of acquired securities. The representative goods producer owes a bank an amount $Q_{t} S_{t} R_{k t+1}$ at the end of the period. This value equals the sum of profits $\Pi_{f t}$ obtained through capital utilization in production (gross of capital remuneration) and the market value of the effective nondepreciated capital, that could be sold back in the market after production has taken place.

$$
Q_{t} S_{t} R_{k t+1}=\Pi_{f t+1}+(1-\delta) Q_{t+1} K_{t+1}
$$

Substituting for $\Pi_{f t}$ and $S_{t}$ and dividing both sides by $K_{t+1}$ :

$$
Q_{t} R_{k t+1}=\alpha \frac{Y_{t+1}}{K_{t+1}}+(1-\delta) Q_{t+1}
$$

Hence, the gross return to capital in period $t+1$ is given by the ratio between the value generated by one unit of capital acquired by the firm in period $t$ over the price at which it was bought.

$$
R_{k t+1}=\frac{Z_{t+1}+(1-\delta) Q_{t+1}}{Q_{t}}
$$

\subsection{Capital producers}

The market for capital is competitive. At the end of each period, capital producers build new capital for the following period using the final output as an input in the production. Capital goods are then sold back to goods producers at price $Q_{t}$. They are subject to 
convex adjustment costs in this process. ${ }^{10} \mathrm{~A}$ capital producer chooses investment $I_{t}$ in order to maximize discounted profits, taking the price of capital $Q_{t}$ as given.

Adjustment costs are a convex function of investment. The capital producers' problem is given by:

$$
\max \quad E_{t} \sum_{\tau=t}^{\infty} \beta^{\tau-t} \Lambda_{t, \tau}\left[Q_{\tau} I_{\tau}-\left[1+f\left(\frac{I_{\tau}}{I_{\tau-1}}\right)\right] I_{\tau}\right]
$$

with $f(1)=f^{\prime}(1)=0$ and $f^{\prime \prime}(1)>0$. Non-zero profits are possible when the economy is not in steady state, and profits are transfered to the household.

The first order condition for investment is given by:

$$
Q_{t}=1+f\left(\frac{I_{t}}{I_{t-1}}\right)+\frac{I_{t}}{I_{t-1}} f^{\prime}\left(\frac{I_{t}}{I_{t-1}}\right)-E_{t} \beta \Lambda_{t, t+1}\left(\frac{I_{t+1}}{I_{t}}\right)^{2} f^{\prime}\left(\frac{I_{t+1}}{I_{t}}\right)
$$

This condition states that capital price will equal the marginal cost of investment.

The adjustment cost function assumes the form:

$$
f(.)=\frac{\eta_{i}}{2}\left(\frac{I_{t}}{I_{t-1}}-1\right)^{2}
$$

where $\eta_{i}$ refers to the inverse elasticity of investment with respect to the price of capital.

\subsection{Government}

Government spending is given by $G_{t}$. To finance itself, government taxes households, banks and issues debt, which for simplicity is bought only by banks.

The government issues debt with the following maturity structure: every period a fraction $\mu$ of the outstanding debt stock comes due and $1-\mu$ goes on to add to the next period's debt pile. This is equivalent to assuming the government always issues debt with varying maturities, being $1-\mu$ the ratio between the amount of debt coming due in $t+1$ and the amount coming due in $t$.

The objective of the paper is to study fiscal policy in the aftermath of a sovereign default. To capture the debt restructuring in an easily tractable way we assume the default is caused by an exogenous policy shock. We introduce this possibility in the model by assuming that repayment is given by a random variable $m_{t} \in[0,1]$. The variable $m_{t}$ represents the actual fraction of debt coming due at $t$ that is repaid, and it is given by:

$$
m_{t}=\min \left\{\iota_{t}, 1\right\}
$$

\footnotetext{
${ }^{10}$ As pointed out by Gertler and Kiyotaki (2010), adjustment costs enhance the quantitative performance of the model without adding much complication.
} 
where

$$
\iota_{t}=\rho_{\iota} \iota_{t-1}+\left(1-\rho_{\iota}\right)+\varepsilon_{\iota t}
$$

where $\rho_{\iota}$ is a positive constant and $\epsilon_{\iota t}$ is a normally distributed error term with mean 0 and standard deviation $\sigma_{\iota}$. In steady state, $\iota_{t}=1$, meaning that the government fully repays the amount of debt that comes due in $t$. However, the fraction to be repaid is subject to shocks.

A debt restructuring episode triggered by a policy decision is captured by a one-off negative shock on $\iota$. The auto-regressive specification captures the fact that in case of debt restructuring, sovereigns tend to repudiate short term debt in order to lengthen the debt repayment profile. So repayment drops in the first periods following a default episode but grow in time, tending again to a hundred percent of the maturing fraction as the shock vanishes completely. ${ }^{11}$ The following section shows that in fact such a pattern was present in the Greek Bond Exchange from 2012.

In each period, the government repays $\mu m_{t}$ of the debt. Denoting $\chi_{t}$ the price of debt, the government's financing requirement for period $t+1, \chi_{t} A_{t+1}$, is the difference between the fraction of debt repaid ( $\mu B_{t}$ times the fraction effectively honoured $m_{t}$ ) and the amount of government spending that is not covered by taxes (primary deficit):

$$
\chi_{t} A_{t+1}=\mu m_{t} B_{t}+G_{t}-T_{t}
$$

Total outstanding (nominal) debt in $t+1$ is given by:

$$
B_{t+1}=(1-\mu) B_{t}+A_{t+1}
$$

Total taxes are given by the sum of all sources of taxation: lump-sum transfers, consumption taxes, income taxes (wage income and capital taxes) and taxes on banks' profits (to be presented in the next subsection).

$$
T_{t}=T R_{t}+\tau_{t}^{c} C_{t}+\tau_{t}^{w} W_{t} L_{t}+\tau_{t}^{d}\left(R_{t}-1\right) D_{t}+\tau_{t}^{b} \pi_{t}
$$

The government will follow some form of (autoregressive) tax rule, that prevents debt from deviating largely from steady state. These rules will be presented later in the paper when we talk about calibration.

To complete this subsection, gross return on bonds is the ratio between the expected value to be payed back by the government in the next period plus the expected value of the remaining outstanding debt divided by the current price of debt:

$$
R_{b t+1}=\frac{\mu E_{t} m_{t+1}+(1-\mu) E_{t} \chi_{t+1}}{\chi_{t}}
$$

\footnotetext{
${ }^{11}$ Besides allowing for the simulation of a debt restructuring episode, this specification can also capture the fact that sovereign debt is risky. The standard deviation of $\epsilon_{\iota t}$ can be calibrated to capture this risk.
} 
A shock to $m_{t}$ affects not only the haircut in $t$, but also the expected repayment in the following periods, which induces changes in bonds' prices, directly influencing banks' balance sheets and investment decisions. Steady state price of government debt $\chi_{t}$ is:

$$
\bar{\chi}=\frac{\mu}{\bar{R}_{b}-(1-\mu)}
$$

In the limiting case where $\mu=1$, price of debt is as standard the inverse of the bond yield.

\subsection{Banks}

Following Gertler and Karadi (2011), banks can raise funds from households in form of deposits or from retained earnings, accumulating net worth. They use the available funds to buy state-contingent securities from goods producers, but also to buy government bonds $B_{t+1}$ at price $\chi_{t}$. Banks are the only agents that buy sovereign debt in this economy. We also assume that banks pay each period a tax $\tau_{t}^{b}$ on their profits.

A bank's balance sheet is composed by the assets it holds (government bonds and private securities), liabilities (deposits) and net worth:

$$
\chi_{t} B_{t+1}+Q_{t} K_{t+1}=N_{t}+D_{t+1}
$$

$D_{t}$ are deposits raised from households and we used $S_{t}=K_{t+1}$.

We make use of the notation $N_{t}$ to denote post-tax net worth:

$$
N_{t}=N_{t-1}+\pi_{t}\left(1-\tau_{t}^{b}\right)
$$

with

$$
\pi_{t}=r_{t}^{k} Q_{t-1} K_{t}+r_{t}^{b} \chi_{t-1} B_{t}-r_{t} D_{t}
$$

Net worth in $t+1$ is the gross payoff from assets funded at $t$ net of returns to depositors. Profits are given by subtracting the flow of compensation to depositors from earnings on assets. Let $R_{k t+1}$ denote the gross rate of return on a unit of a bank's private securities from $t$ to $t+1$. Net worth before taxes is then given by:

$$
\tilde{N}_{t+1}=R_{k t+1} Q_{t} K_{t+1}+R_{b t+1} \chi_{t} B_{t+1}-R_{t+1} D_{t+1}
$$

with

$$
R_{k t+1}=\left(1+r_{t+1}^{k}\right)=\frac{Z_{t+1}+(1-\delta) Q_{t+1}}{Q_{t}}
$$

The objective of a banker is to maximize its future terminal value, given by the discounted value of (net) net worth, accounting for the probabilities that she might exit at 
each future period:

$$
V_{t}=E_{t}\left[\sum_{i=1}^{\infty}(1-\theta) \theta^{i-1} \beta^{i} \Lambda_{t, t+i} N_{t+i}\right]
$$

The bank's ability to obtain funds is limited by a moral hazard constraint as in Gertler and Karadi (2011). At each period, a banker may choose to divert a fraction $\lambda$ of assets in the form of dividends to her family and hence defaults on part of debt. In this case, the remaining fraction $1-\lambda$ of her assests will be recovered by other depositors, leading the bank to bankruptcy. This fraction $\lambda$ is exogenous and constant. This constraint could also be interpreted as a leverage constraint imposed by official regulation, along the lines of the Basel Agreements. In equilibrium, leverage is pinned down by this constraint.

Anticipating the possibility of funds diversion, depositors will limit their lendings to ensure banks won't divert funds. The bank's value must be at least as large as its gain from deviating funds, so as to discourage diversion.

$$
V_{t} \geq \lambda\left(\chi_{t} B_{t+1}+Q_{t} K_{t+1}\right)
$$

The expressions in (16) and (17) yield the evolution of the bank's net worth as a function of the state variables $K_{t}, B_{t}$ and $N_{t-1}$ :

$$
N_{t}=N_{t-1}+\left[\left(r_{t}^{k}-r_{t}\right) Q_{t-1} K_{t}+\left(r_{t}^{b}-r_{t}\right) \chi_{t-1} B_{t}+r_{t} N_{t-1}\right]\left(1-\tau_{t}^{b}\right)
$$

Let $V_{t}\left(K_{t+1}, B_{t+1}, N_{t}\right)$ be the maximized value of the bank's objective. It will satisfy the following Bellman equation.

$$
V_{t}\left(K_{t+1}, B_{t+1}, N_{t}\right)=E_{t} \beta \Lambda_{t, t+1}\left\{(1-\theta) N_{t+1}+\theta \max \left[V_{t+1}\left(K_{t+2}, B_{t+2}, N_{t+1}\right)\right]\right\}
$$

In each period, the banker chooses a portfolio composition of capital and bonds, $K_{t+1}$ and $B_{t+1}$, in order to maximize her value function subject to the incentive constraint and the law of motion for net worth, taking into account that she might exit with probability $(1-\theta)$.

We conjecture the value function to be linear in the balance sheets' components:

$$
V_{t}\left(K_{t+1}, B_{t+1}, N_{t}\right)=\nu_{t} Q_{t} K_{t+1}+\zeta_{t} \chi_{t} B_{t+1}+\eta_{t} N_{t}
$$

In the Appendix we show that this conjecture is true, as long as:

$$
\begin{gathered}
\eta_{t}=E_{t} \beta \Lambda_{t, t+1} \tilde{\Omega}_{t+1}\left[1+r_{t+1}\left(1-\tau_{t+1}^{b}\right)\right] \\
\nu_{t}=E_{t} \beta \Lambda_{t, t+1} \Omega_{t+1}\left(R_{k t+1}-R_{t+1}\right) \\
\zeta_{t}=E_{t} \beta \Lambda_{t, t+1} \Omega_{t+1}\left(R_{b t+1}-R_{t+1}\right)
\end{gathered}
$$


with

$$
\Omega_{t}=\left(1-\tau_{t}^{b}\right) \tilde{\Omega}_{t}
$$

and

$$
\tilde{\Omega}_{t+1}=1-\theta+\theta\left[\phi_{t+1} \zeta_{t+1}+\varpi_{t+1}\left(\nu_{t+1}-\zeta_{t+1}\right)+\eta_{t+1}\right]
$$

The auxiliary variable $\varpi_{t}$ is the leverage only in terms of capital:

$$
\varpi_{t} \equiv \frac{Q_{t} K_{t+1}}{N_{t}}
$$

Each component of the banks' value function can be interpreted as follows: $\eta_{t}$ is saving in deposits' costs from an additional unit of net worth. The variables $\nu_{t}$ and $\zeta_{t}$ are the marginal discounted gains of expanding, respectively, private securities' holdings and government bonds' holdings. Finally, $\tilde{\Omega}_{t}$ is the shadow marginal value of net worth and affects the banks' intertemporal discount factor.

Optimization for banks will imply the following no-arbitrage condition:

$$
E_{t} \beta \Lambda_{t, t+1} \Omega_{t+1}\left(R_{k t+1}-R_{t+1}\right)=E_{t} \beta \Lambda_{t, t+1} \Omega_{t+1}\left(R_{b t+1}-R_{t+1}\right)
$$

Define $\phi_{t}$ as the leverage ratio, the maximum ratio of bank assets over equity:

$$
\phi_{t} \equiv \frac{Q_{t} K_{t+1}+\chi_{t} B_{t+1}}{N_{t}}
$$

The constraint in (19) can be rewritten as:

$$
\nu_{t} Q_{t} K_{t+1}+\zeta_{t} \chi_{t} B_{t+1}+\eta_{t} N_{t} \geq \lambda\left(\chi_{t} B_{t+1}+Q_{t} K_{t+1}\right)
$$

If this constraint binds, we get:

$$
\phi_{t}=\frac{\eta_{t}+\varpi_{t}\left(\nu_{t}-\zeta_{t}\right)}{\lambda-\zeta_{t}}
$$

Which, using (29), simplifies to:

$$
\phi_{t}=\frac{\eta_{t}}{\lambda-\zeta_{t}}
$$

\subsection{Evolution of bank's net worth}

The total net worth in the banking sector equals the sum of existing banks' net worth $N_{e, t}$ and entering banks' start-up capital $N_{n, t}$ provided by their families. The net worth of existing banks equals the net earnings from assets over liabilities from one period to another, i.e., earnings from holding securities plus earnings from holding government 
bonds, minus costs from deposits, net of taxes. This expression must be multiplied by the fraction $\theta$ of banks that survive between periods:

$$
N_{e, t}=\theta N_{t-1}+\theta N_{t-1}\left(1-\tau_{t}^{b}\right)\left[\left(R_{k t}-R_{b t}\right) \varpi_{t-1}+\left(R_{b t}-R_{t}\right) \phi_{t-1}+\left(R_{t}-1\right)\right]
$$

Families transfer to each new banker a constant fraction $\omega /(1-\theta)$ of total assets from exiting bankers, given by $(1-\theta)\left[Q_{t} K_{t}+\chi_{t} B_{t}\right]$, also after taxes. Hence entering bankers' net worth will be:

$$
N_{n, t}=\omega\left(1-\tau_{t}^{b}\right)\left(Q_{t} K_{t}+\chi_{t} B_{t}\right)
$$

Total net worth from banks in the economy is thus:

$$
N_{t}=N_{e, t}+N_{n, t}
$$

\subsection{Market clearing}

Output can be used for consumption, government spending or investment (including adjustment costs). Aggregate demand is given by:

$$
Y_{t}=C_{t}+I_{t}\left[1+f\left(\frac{I_{t}}{I_{t-1}}\right)\right]+G_{t}
$$

Market clearing in the goods market requires the expression for demand in (33) to equal supply, given by (5).

The banks' balance sheet can be written as:

$$
Q_{t} K_{t+1}+\chi_{t} B_{t+1}=\phi_{t} N_{t}
$$

Demand for securities and bonds is given by the balance sheet constraint, given by (30). The supply of securities by firms is given by the expression for capital accumulation:

$$
K_{t+1}=(1-\delta) K_{t}+I_{t}
$$

Finally, market clearing for deposits is obtained from balance sheet identity. Total deposits supplied by families must equal the difference between banks' assets and net worth.

$$
D_{t}=Q_{t} K_{t+1}+\chi_{t} B_{t+1}-N_{t}
$$

\section{Calibration}

In order to study how fiscal policy in the aftermath of debt restructuring affects the sovereign-bank loop, we use the model from Section 2 to simulate a debt restructuring 
episode and run a series of counterfactual exercises, with different fiscal policy responses. The model economy is calibrated to capture the sovereign-bank loop in the Greek economy on the verge of the 2012 debt restructuring episode. We thus begin this section by briefly describing this case.

\subsection{The Greek Debt Restructuring}

The 2012 Bond Exchange in Greece was the outcome of a public budget deterioration that became evident with the countercyclical policies following the 2007-08 Great Recession and revealed itself much worse once previous unreliable fiscal data was revised. This led to a deep confidence crisis and a sharp increase in spreads for Greek debt. A first proposal for a bond exchange in 2011 (one year after a rescue package had been agreed upon with the IMF and the EU) and the following fiscal consolidation effort by the Greek government were shown to be insufficient, since the deep recession and the postponement of structural reforms precluded a deeper adjustment. After further negotiations a huge bond exchange program was agreed upon for March 2012, with major private sector involvement, a feature already present in the 2011 proposal. ${ }^{12}$

The Greek Restructuring consisted of a lengthening of the average maturity and large debt relief. Restructuring implied an average residual maturity increase for Greek securities from 7 years in 2011 to more than 12 years in 2012, although at the aggregate level the repayment profile for bonds shifted into the future was largely compensated by short term repayment of EFSF (European Financial Stability Facility) notes (official loans). ${ }^{13}$

Figure 1 plots the evolution of debt in aggregated terms and interest payments, both as fractions of GDP. One can observe a drop in general government consolidated debt as a share of GDP from 2011 to 2012, which, in terms of debt relief, resulted in a face value reduction of around $52 \%$, or a reduction of 12 percentage points in Debt/GDP ratio. Notwithstanding this immediate relief, debt-to-GDP ratios started to recover fast, returning to pre-default levels after a few years. The evolution of interest payments in terms of GDP is also interesting: it drops by almost half from 2011Q4 to 2012Q1, after the bond exchange was conducted. Average haircut was $65 \%$, with higher losses for short term investors.

\footnotetext{
${ }^{12}$ For a more detailed account of the Greek Debt Restructuring, see Zettelmeyer et al (2013).

${ }^{13}$ This reflects another important feature of the Greek Restructuring, i.e., a change in composition of debt holders towards official lenders.
} 
Figure 1: Greece: Debt-to-GDP

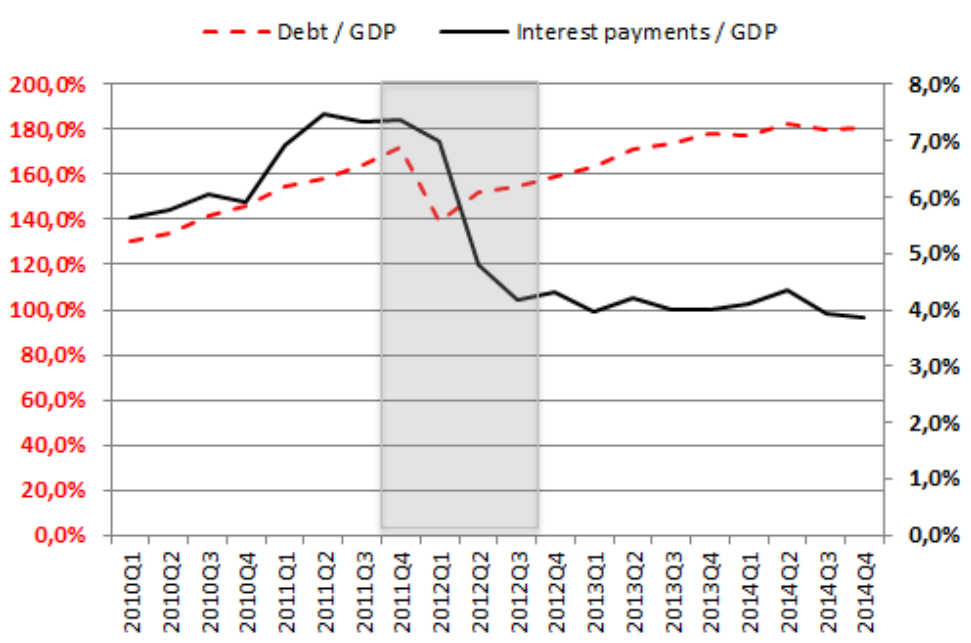

\subsection{Counterfactual Greece}

The Greek Debt Restructuring was accompanied by some degree of fiscal contraction: total taxes were raised and expenditures were cut. Nevertheless, had the restructuring not happened, the fiscal effort required for servicing debt would have probably been much larger than observed. This is precisely the starting point from our exercise.

In our laboratory economy, we consider a counterfactual steady state that aims at capturing a scenario with no Bond Exchange in Greece in 2012. Since the absence of default would have increased substantially debt servicing costs, the debt and tax levels in this counterfactual steady state are higher than their actual values observed in Greece before default. We then simulate a shock that resembles the Greek Bond Exchange from 2012. The restructuring is thus accompanied by expansionary fiscal policy, but that is relative not to reality in 2012 , but to the counterfactual steady state with higher debt and taxes.

To complete the assumptions, we impose that the fiscal room opened right after the restructuring shock is exactly the difference between the counterfactual and the actual debt servicing levels. In the following periods, fiscal policy will react to deviations of debt from steady state such that in the medium run debt returns to pre-default levels. Hence, after a sizeable relief on impact, debt recovers in the medium run, returning to predefault levels after some years. This assumption is in agreement with empirical evidence that suggests debt-to-GDP ratios tend to return, on average, to pre-default levels some years after restructuring. ${ }^{14}$ Hence default opens some fiscal space in the short run, but

\footnotetext{
${ }^{14}$ Benjamin and Wright (2009) estimate an average duration of default episodes of between 7-8 years, starting from
} 
the long run debt burden does not seem to be significantly reduced.

In order to calculate the hypothetical increase in taxes that would have been necessary in the absence of debt restructuring, two assumptions are made: (i) government spending does not change with respect to the value observed in 2012; (ii) the hypothetical debt in the absence of default in 2012 is the debt observed at the end of 2011 times the average year-over-year debt growth between 2008 and 2011. The additional debt service in the absence of default comes from two sources: from the haircut itself, i.e., from the face value reduction of debt; and from the decrease in interest payments over debt. ${ }^{15}$

This additional debt servicing need is the extra amount of tax revenues that would have been required in the absence of restructuring. Table 1 compares variables observed in 2012 and their counterfactuals. In terms of total debt, we calculate an increase in debtto-GDP of 46 percentage points in comparison to the one observed after restructuring. This implies additional taxes of almost 4 p.p. in terms of GDP. Taking into account only government debt held by banks (the share that we consider in the model), we observe an even larger increase relative to the value observed in 2012. This is due to the change in composition of lenders, that left private agents with little participation in debt holdings after the bond exchange. In terms of debt servicing needs, the reduction was in the region of $40 \%$.

\subsection{Calibration}

Sovereign debt restructuring affects an economy in a variety of ways. Our model and calibration aim at capturing the sovereign-bank channel only. Hence, default on debt in the hands of households or foreign agents is not considered in our simulations. Our calibration matches key features of the Greek economy surrounding the March 2012's Bond Exchange. The model's steady state portrays Counterfactual Greece in 2012 and the default shock captures the main characteristics of the observed debt restructuring.

\subsubsection{The Fiscal Rule}

Figure 2 presents revenues per type of tax as a share of total taxes in 2012, calculated using data from Eurostat on tax items and aggregating by categories. The model is

\footnotetext{
declaration of default until the resolution of the negotiations. They also find that after this period, face value debt-to-GDP is already $5 \%$ higher than before default announcement for the median country. Nevertheless, the increase in average debt maturity and the fall in interest rates provide some degree of debt relief.

${ }^{15}$ The first effect is given by the difference between hypothetical debt and observed debt, multiplied by the average interest rate from 2007 to 2011. The second is the observed debt times the difference in the average interest rate before and after the bond exchange. The interest rate considered for this calculations is the ratio between interest payments and total debt, using data from Eurostat.
} 
Table 1: Counterfactuals for Model Simulation

\begin{tabular}{l|c|cc|ccc}
\hline \hline \multicolumn{2}{l|}{} & \multicolumn{2}{c|}{2012 (total debt) } & & \multicolumn{2}{c}{2012 (only banks' debt) } \\
\hline \multicolumn{2}{l|}{2011} & Observed & Counterfactual & 2011 & Observed & Counterfactual \\
\hline Debt* & 356,289 & 305,094 & 393,386 & 59,092 & 28,218 & 65,448 \\
Debt/GDP** & $172 \%$ & $160 \%$ & $206 \%$ & $28 \%$ & $15 \%$ & $34 \%$ \\
Taxes & 47,323 & 46,706 & 53,466 & & 47,831 \\
Taxes/GDP & $22.9 \%$ & $24.4 \%$ & $28.0 \%$ & & $25.0 \%$ \\
Var(\%) (2012/counterf - 1) & & & $-12.6 \%$ & & $-2.4 \%$ \\
Debt Service*** & 9,743 & 16,503 & & 1,621 & 2,746 \\
Savings from default & & 6,760 & & 1,125 \\
Var(\%) (2012/counterf - 1) & & $-41.0 \%$ & & $-41.0 \%$ \\
\hline \hline
\end{tabular}

*General Government Consolidated Gross Debt (million Euros)

**Assuming the same GDP for Counterfactual Greece

***Average interest rate before default: $4,2 \%$; Interest rate in 2012 : $3,2 \%$

calibrated to match this tax composition. 'Other' taxes are bundled as lump sum taxes.

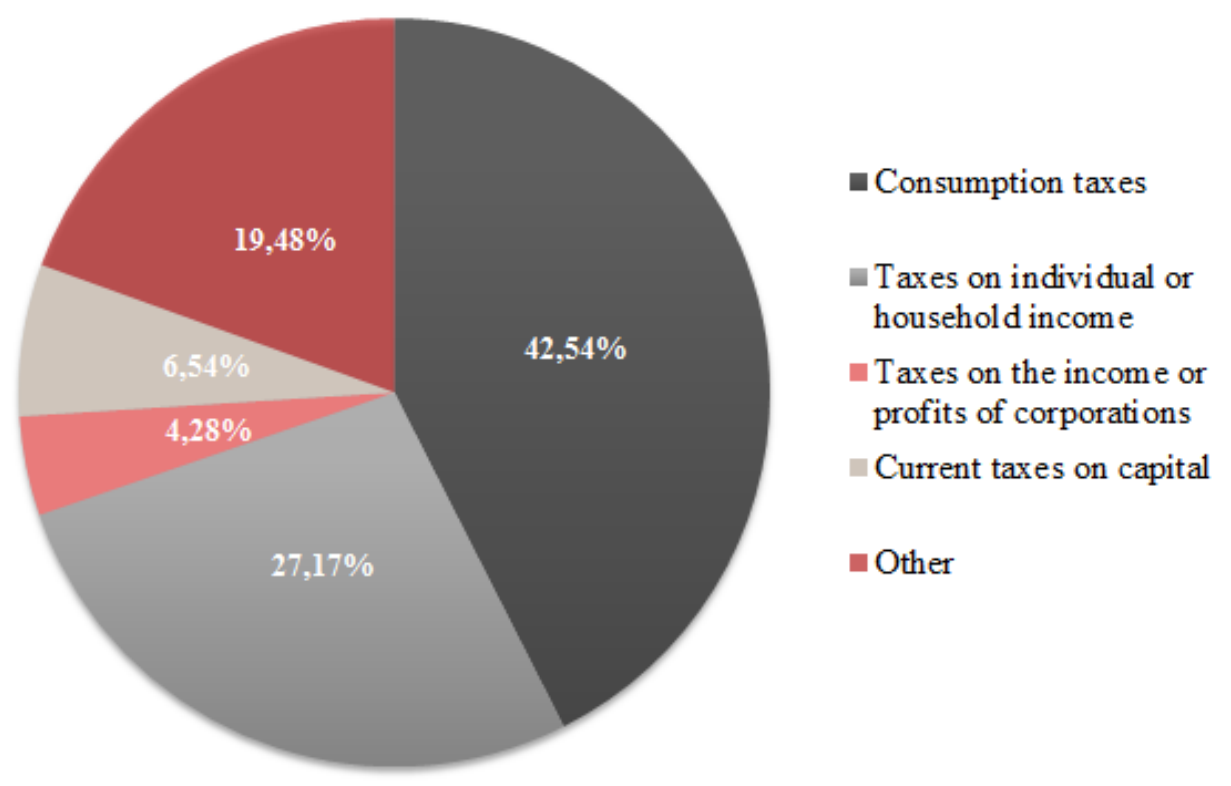

Figure 2: Tax rates for selected items

Source: Authors' calculations using data from Eurostat

Table 1 shows that total tax revenues in case of default are $2.4 \%$ lower than in Counterfactual Greece, when we consider bank's debt only. We target this amount of tax reduction when default hits the economy and compare the response of the economy allowing one tax rate to be cut at a time, calibrating the rule parameter to achieve this size of decrease on impact for each tax. 
We now turn to the fiscal rules assumed to close the model. The government has a set of tax rates to manipulate and can also increase exogenous expenditures, with the objective of not letting real value of debt deviate largely from steady state. The speed of this adjustment is given by the parameter $\rho_{b}$ and is related to the convergence of debt to the steady state level. Tax rates also have an autoregressive component, $\rho_{x}$, as in the following equation:

$$
X_{t}=\left(1-\rho_{x}\right) \bar{X}+\rho_{x} X_{t-1}+\rho_{b}\left(\chi_{t} B_{t}-\bar{\chi} \bar{B}\right)
$$

with

$$
X_{t}=\left\{\tau_{t}^{w}, \tau_{t}^{c}, \tau_{t}^{d}, \tau_{t}^{b}, T R_{t}, G_{t}\right\}
$$

The parameter $\rho_{b}$ is calibrated to target desired response of taxes after the shock (it assumes negative values in case of government expenditures), that match both the initial desired drop in taxes and the time until debt converges again to steady state in line with the already mentioned empirical evidence on default. Across the exercises we compare scenarios for which the government uses one tax instrument at a time, leaving the other tax rates fixed at steady state values. The autoregressive component of the tax rule, $\rho_{x}$, is set to 0.9 and is also subject to variations in sensitivity analyses.

\subsubsection{Parameters and Steady States}

In order to match the main characteristics of the Greek macroeconomy in 2012, government consumption is set to $21.3 \%$ of GDP, gross capital formation is $12 \%$ of GDP and consumption comprises the remaining fraction $(66.7 \%)$, given that we consider a closed economy. These values are almost exactly the ratios found in data for Greece in 2012 (Eurostat), with deviations corresponding to net exports, that are not accounted for in the model.

For the "real" sector, we set desired risk premium that, together with depreciation rate and capital share in output, determine the capital/labour ratio for the economy. In order to match those ratios we set depreciation rate $(\delta)$ to $8.5 \%$ per year, capital share in production $(\alpha)$ to 0.33 and the intertemporal discount rate $(\beta)$ to 0.98 . The steady state spread of capital return over the risk free rate, $R_{k}-R$, that in the model also represents spread from bond return over risk free $R_{b}-R$, is set to $5.8 \%$ per year. This value is close to the annualized spread of 10-year Greek bonds over German bonds observed in 2010. ${ }^{16}$

\footnotetext{
${ }^{16}$ We opted for this value that reflects better a longer run equilibrium rate, instead of the very volatile spreads observed from mid-2011 until 2012, reflecting market uncertainty surrounding the negotiations of the Greek default. Indeed, when calculating debt relief achieved with default in Greece, Zettelmeyer et al (2013) opt for a discount rate that reflects expected future borrowing conditions, which would hang from 3.5 to $8 \%$ per year.
} 
Table 2: Parameters

\begin{tabular}{c|c|l}
\hline \hline \multicolumn{3}{c}{ Households } \\
\hline$\beta$ & 0.98 & Intertemporal discount rate \\
$\sigma$ & 1 & Intertemporal elasticity of substitution \\
$\psi$ & 1 & Labour weight in utility \\
$\varphi$ & 3 & Inverse elasticity of labour supply \\
\hline \multicolumn{2}{|c}{ Financial Intermediaries } \\
\hline$\lambda$ & 0.47 & Fraction of assets that can be diverted \\
$\omega$ & 0.003 & New banks initial capital transfer \\
$\theta$ & 0.89 & Banks survival rate \\
\hline \multicolumn{2}{|}{} \\
\hline$\alpha$ & 0.33 & Capital share in production function \\
$\delta$ & 0.085 & Exogenous depreciation rate (yearly) \\
$\eta_{i}$ & 1.7 & Inverse elasticity of investment to capital price \\
\hline \hline
\end{tabular}

Inverse elasticity of investment to capital price, $\eta_{i}$, follows the conventional value from papers that add adjustment costs to investment, such as Gertler and Karadi (2011).

Parameters of the GHH preferences follow conventional calibration in the literature. Labour disutility equals 1 and the Frisch inverse elasticity of labour supply, $\varphi$, is set to 3 , implying a labour supply elasticity equal to $1 / 3$. In case of labour income taxes, these values imply that the Laffer curve peaks when the labour tax rate is around $75 \% .{ }^{17}$ Table 2 summarizes the parameters in our calibration.

The other set of aggregates regards debt and banks (the "financial side"). We target two key ratios: debt as a fraction of total assets and the leverage ratio. Since our focus is to study the sovereign-debt loop, public debt is held by banks only. To calibrate debt as a fraction of total assets we use consolidated data from the Bank of Greece on Balance Sheet of Credit Institutions. Denoting debt as the sum of securities and loans to the domestic government and assets as the sum of all domestic assets (to roughly reflect our closed economy), we arrive at a value of $16 \%$ for debt/assets, also in line with evidence presented by Gennaioli, Martin and Rossi (2013). This data also provide government debt as share of total debt equal to $29 \%$, which is Debt/GDP in our model. Recalling that we model a counterfactual steady state with a higher Debt/GDP equal to $206 \%$, we adjust the values mentioned above proportionately and set steady state debt/assets to $18 \%$, which gives a value of $32 \%$ for Debt/GDP.

\footnotetext{
${ }^{17}$ Trabant and Uhlig (2011) characterize Laffer curves for EU countries in a neoclassical growth model featuring constant Frisch elasticity preferences. They find an average peak that goes from 62 to $68 \%$, which would imply a larger elasticity of labour supply and thus strengthen our results when this labour taxes are used.
} 
Leverage ratio is set to 6.5, in line with Bankscope data on Greek banks, most of them important creditors of their own government. ${ }^{18}$ Parameters that determine leverage in the model are $\lambda$ and $\omega$, respectively, the share of divertable assets and the initial capital transfer to new bankers.

We then choose $\mu$ accordingly to reach a debt's term to maturity equal to 7.4 years, the value observed in data before the restructuring. As already mentioned, we only focus on the specific channel of default through balance sheets of banks. Besides, we do not account for important movements in debt's composition after default that, as shown in the previous section, moved towards higher participation of official lenders' loans in expense of privately held securities, the share of total debt directly affected by the bond exchange.

Concerning the fiscal block of the model, steady state government consumption and debt service imply taxes are $26 \%$ of GDP, a value slighly higher than the counterfactual one presented in the previous section. Table 3 shows model steady state aggregates and ratios and comparison to Counterfactual Greece. Details on the time series used and assumptions are in appendix.

\subsubsection{The Debt Restructuring Exercise}

As previously displayed, the bond exchange in Greece had two important features: a substantial lengthening of the repayment profile and a considerably high average haircut, leading to a present value debt relief of almost $50 \%$ in terms of GDP (Zettelmeyer et al, 2013). To match those two features, we set persistence of the shock to 0.93 and the standard deviation to 0.8 , which imply the shock does not fade away during the simulation horizon. Those values refer to, respectively, $\rho_{\iota}$ and $\sigma_{\iota}$. As showed in Figure 3 this two parameters from our shock specification match pretty closely actual haircuts according to debt maturity, as calculated in Zettelmeyer et al (2013).

The baseline tax response targets the difference between taxes in the (counterfactual) steady state and the one observed in data for 2012. We target a reduction of $2.4 \%$ on impact in aggregate taxes and calibrate $\rho_{b}$ for each tax rate to match this reduction. We compare the response of the economy by letting one tax component react according to the fiscal rule at a time, leaving fixed the other tax rates.

As for the face value reduction, endogenous effects might produce an initial impact that might be slightly different from the targeted $50 \%$ drop due to endogenous response

\footnotetext{
${ }^{18}$ Leverage in the model corresponds to the fraction of banks' total assets over net worth. Using data on banks Tier1 Capital or Total Capital for net worth, we find an average for 2010-12 respectively, of 7.2 and 5.1, so we opt to use a value close to the average of both, which is 6.1 .
} 
Table 3: Model Steady States and comparison to Data

\begin{tabular}{l|c|c}
\hline \hline Variable & Model SS & ${\text { Data } \text { (counterfactual }^{\dagger} \text { ) }}^{\text {Private Consumption / GDP (\%) }}$ \\
Fixed Capital Formation / GDP (\%) & 66.7 & 67.4 \\
Government Consumption / GDP (\%) & 12.0 & 12.8 \\
Debt / GDP (\%) & 21.3 & 21.7 \\
Term to Maturity (years) & $7.7^{*}$ & $28.5(33.5)$ \\
Leverage Ratio & 6.5 & 7.4 \\
Debt / Total Assets (\%) & 18.2 & $6.1 * *$ \\
Spread (year) (\%) & 5.8 & $16.2(19.2)$ \\
Taxes / GDP (\%) & 26.0 & $24.4(25.1)$ \\
Income Tax / Total Taxes (\%) & 27.0 & 27.2 \\
Wages and Salaries / Interest on Deposits (\%) & 83.5 & 82.0 \\
Wage Taxes / Total Taxes (\%) & 22.2 & 22.3 \\
Deposit Taxes / Total Taxes (\%) & 4.9 & 4.9 \\
Consumption Taxes / Total Taxes (\%) & 42.4 & 42.5 \\
Bank Taxes / Total Taxes (\%) & 1.8 & $1.8^{* * * *}$ \\
Other Taxes / Total Taxes (\%) & 28.8 & 28.6 \\
\hline \hline
\end{tabular}

*Data sources and details in appendix.

$\dagger$ Values in parentheses refer to the counterfactuals calculated from data.

*Debt/GDP in the model: $\chi B / 4 Y$. **Average 2010-2012. ***2010. ****Average 2001-08.

Figure 3: Actual (left panel) and Simulated (right panel) Haircuts
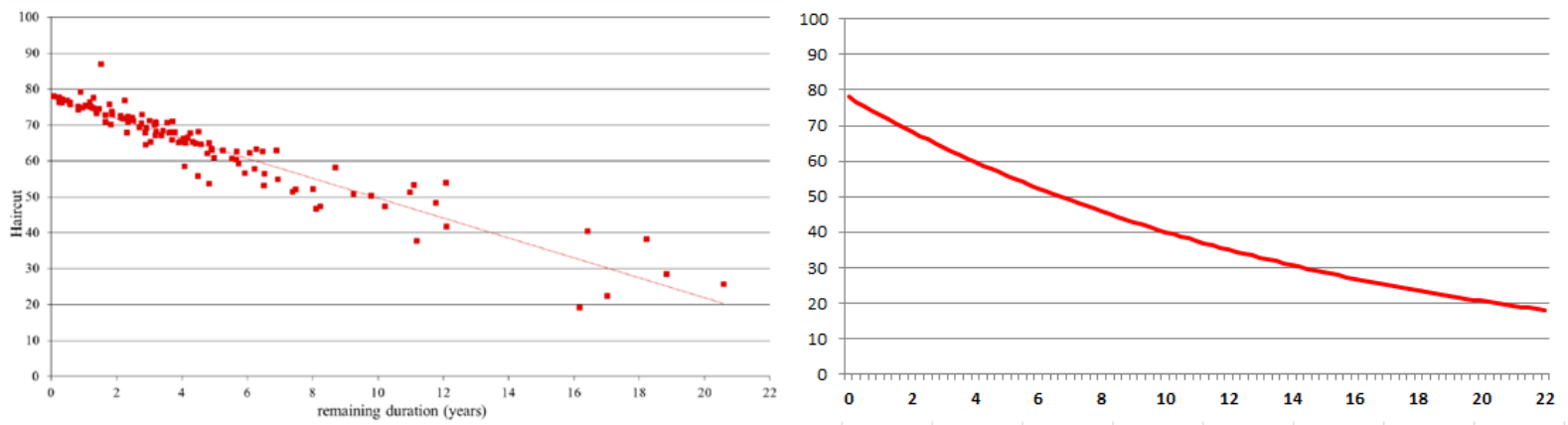

Source of actual haircuts: Zettelmeyer et al (2013)

of other model's variables when taxation is distortionary, what might affect debt price.

\section{Results}

The steady state of the model represents a situation with no default and, consequently, with an amount of taxes and government spending that allows for serving the full debt. 
Debt default would either change (reduce) the amount of taxes required for debt repayment or allow for more government spending. In this section, we study how sovereign debt restructuring coupled with different fiscal policy responses affects the sovereign-bank loop.

The fiscal response following a sovereign default can differ in two main dimensions: (i) the difference in tax revenues between the default and the counterfactual scenario can come from changes in different taxes; and (ii) the post-default amount of debt can evolve in different ways. For the first point, we study the effect of a sovereign debt restructuring shock coupled with a reduction (compared to a counterfactual scenario with no default) in (i) lump sum taxes; (ii) increases in government purchases; (iii) taxes on consumption; (iv) taxes on labour; (v) taxes on return on capital; and (iv) taxes on banks. In order to deal with the second point, we allow for different speeds of convergence of the level of debt to the steady state - while always assuming that, consistently with the empirical evidence, debt eventually comes back to its pre-default level.

Simulations were conducted using Dynare. The results presented in the paper consider a first order approximation around the steady state of the model. In Appendix C, we show the conclusions are robust to changes in consumers' preferences (our baseline exercises employ a GHH utility function) and in the tax rule.

\subsection{Changes in different taxes}

\subsubsection{Lump sum taxes}

In our baseline exercise, we consider a fiscal rule that allows only for changes in lump sum taxes, leaving other tax rates constant at their steady-state values. Lump sum taxes are not common in the real world, but feature in several models exploring the nexus between sovereign and bank credit risk. ${ }^{19}$ Figure 4 shows the impulse responses. In comparison to the counterfactual presented in Table 1, this scenario considers a fall in lump sum taxes calibrated to generate a $2.4 \%$ drop in tax revenues on impact.

The price of debt falls by more than $40 \%$ and recovers slowly in line with the haircut dynamics. The value of debt among banks' assets drops by the targeted $50 \%$ on impact. The ensuing financial disruption is translated into a fall in the price of capital. The mechanism is the following: the decline in banks' net worth together with their leverage constraint forces banks to deleverage, leading to a fire sale of assets. Capital prices thus drop and private credit is reduced. This leads to an investment drop. The drop in asset demand by banks is reflected in the increase of the spread of capital returns over the risk-free rate on deposits.

\footnotetext{
${ }^{19}$ Examples include Boccola (2016) and Perez (2015).
} 
Figure 4: Response to debt restructuring with a change in lump sum taxes
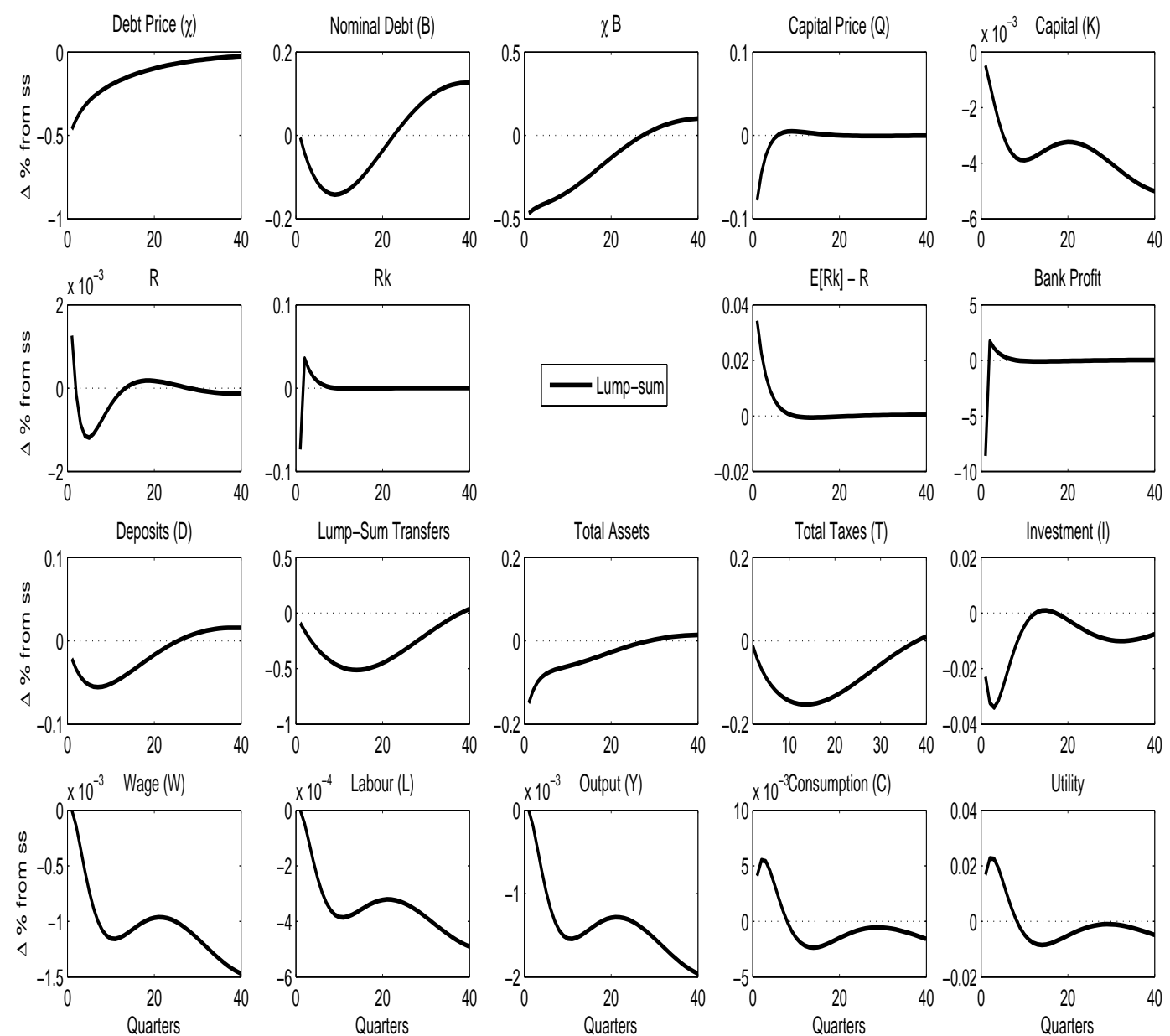

The result is a very persistent but mild fall in the level of capital and output. The present value of output deviations is $1.3 \%$ of (yearly) GDP. Wages and labour supply behave in a similar way. A transfer from banks to the government leads to a fall in economic activity owing to the effects of this transfer on banks' balance sheets.

In Section 4.2, we will show that the financial disruption stemming from the sovereignbank loop has a more severe impact on the economy in case fiscal policy is more lax and the level of debt quickly returns to its previous level. In this baseline exercise, face value debt returns to steady state levels around 6 years after default, which is in line with previous evidence from debt restructuring episodes (Benjamin and Wright, 2009; Wright, 
2011).

Next, we show that the conclusions from this section heavily rely on the type of tax considered in the exercise.

\subsubsection{Government spending}

Figure 5 displays the response of the economy when all tax rates are kept fixed and sovereign debt restructuring allows for an increase in government consumption. The increase in $G$ on impact is calibrated to compensate for the 2.4 percentage-point fall on taxes from the counterfactual.

Figure 5: Response to a change in government consumption vs. lump-sum taxes
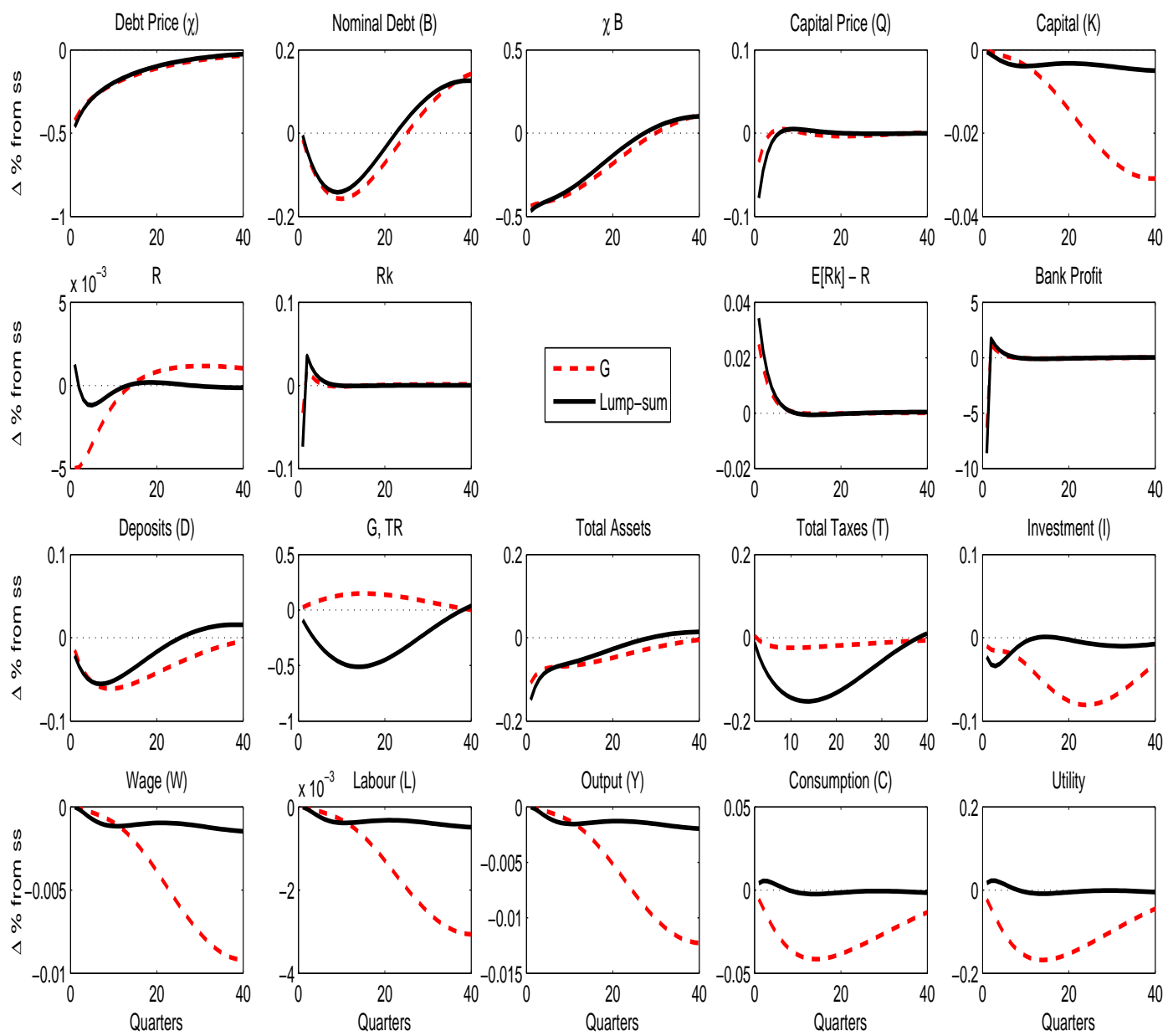
In the short run, the effect on capital and output is similar to the case with lump sum taxes. However, after around 10 quarters, the difference between both cases is very pronounced. The increase in government consumption following default crowds-out private consumption and investment, contributing to worsen the diabolic loop. Owing to this crowding out effect, the effects of the financial disruption are very persistent. Investment and consumption reach, respectively, a $10 \%$ and $5 \%$ fall in the medium run, and output is almost $2 \%$ below its steady state after 10 years.

Hence, in our laboratory economy, restructuring debt instead of cutting government expenditures leads to a fall in investment and consumption owing to the ensuing financial disruption. It follows that cutting government consumption would avoid a deep and also very long recession.

\subsubsection{Taxes on labour income and consumption}

We now consider fiscal rules that allow for changes in labour taxes and in consumption taxes, respectively. In each of these exercises, other tax rates are constant at their steadystate values. One can speculate that labour taxes would be a natural candidate for a tax raise to generate extra revenues and repay debt in the absence of sovereign debt restructuring. Such a conjecture follows from the fact that the Greek Bond Exchange was accompanied by an important change in income tax rates, which increased the share of this specific tax source in total tax revenues $-^{20}$ and while income taxes come from wage taxes and taxes on household savings, the share of income tax revenues originating from wage taxation corresponds to around $80 \%$. Hence the case with labour taxes is a particularly interesting one.

Figure 6 displays the responses of the economy following a sovereign restructuring shock coupled with reductions in labour taxes compared to a case with reductions in consumption taxes. The fall on tax revenues on impact is calibrated to match the $2.4 \%$ fall. Tax rates follow the fiscal rule afterwards. The responses of the economy now are completely different.

With lower income taxes, workers are willing to supply more labour. Pre-tax wages are lower, but post-tax wages are larger. The reaction of labour supply is key to the economy's response. The lower labour costs raise incentives for firms to invest. Interest rates are larger in order to incentivize households to save. The drop in investment is thus

\footnotetext{
${ }^{20}$ Income tax rates in Greece increased by more than $50 \%$ from 2011 to 2012 and decreased a little in 2013 . In contrast, consumption tax rates remained relatively constant. This caused income taxes' share in total taxes to increase by $35 \%$ in comparison to 2011, while the share of consumption taxes decreased by 4 percentage points. Taxes on capital (of various forms) remained more or less constant, although they had increased importantly from 2010 to 2011.
} 
short-lived. The financial disruption is quickly offset by the effect of lower labour costs.

Figure 6: Response to a change in wage and consumption taxes vs. lump-sum taxes
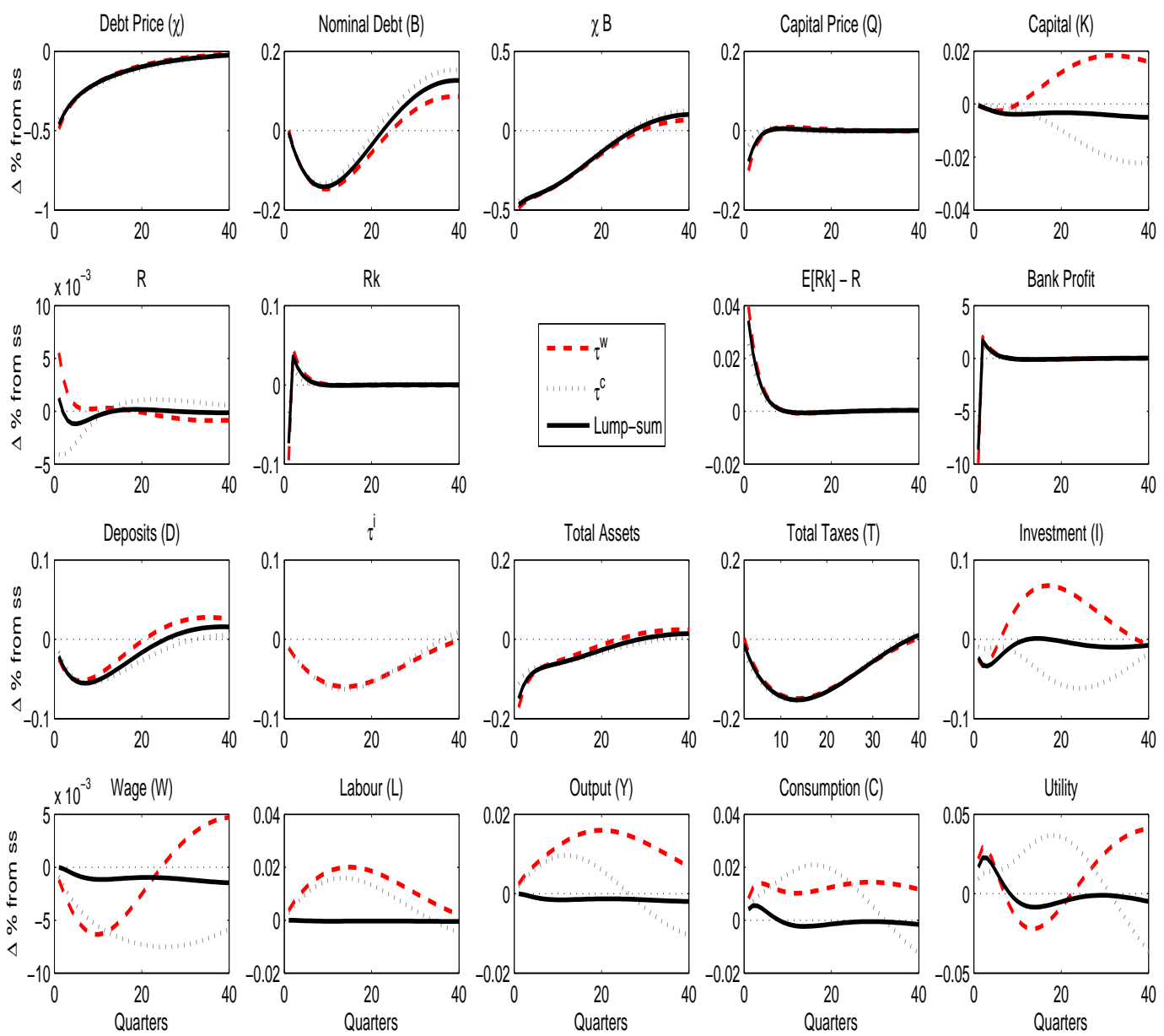

Output goes up despite the initial drop in capital stock. The increase in output reaches $1.5 \%$ after 5 years. Household's utility increases in the short run, following the increase in consumption, drops in the medium run when labour supply is very high and turns positive again in the long run. Overall, households are better off following debt restructuring.

The message from this exercise is that sovereign debt restructuring coupled with a change in labour taxes does not generate a diabolic sovereign-bank loop. The fall in the value of debt does reduce banks' lending capacity, so investment and capital fall in 
the short run. However, the increase in labour taxes required to serve debt would have even more negative effects on the economy. The lower labour taxes (as compared to the counterfactual) boost labour supply and the overall effect is positive. The cost of austerity by means of larger labour taxes beats the cost of financial disruption.

On impact, the response of the economy in the case of consumption taxes is very similar to the case of labour taxes. Both labour and consumption taxes affect the net wage in terms of consumption goods. Hence, initially, the response of pre-tax wages, labour supply and output are similar in both cases.

However, the fall in consumption taxes also reduces the incentives for savings. Indeed, interest rates $R$ fall on impact, deposits fall by more than in the case of labour taxes. As time goes by, we observe a sharp - if delayed - fall in investment. The capital stock in the medium and long run falls. The increase in consumption boosts utility in the short run, but also crowds out investment, so in a few years, consumption, output and household's utility are below their steady-state levels.

In sum, in our laboratory economy, if sovereign debt restructuring comes in place of a hike in consumption taxes, the effect is positive in the short run, but after a few years, the ensuing financial disruption dominates and leads to a fall in economic activity.

\subsubsection{Taxes on capital income and on banks}

Finally we study the response of the economy when sovereign debt restructuring occurs in place of increases in capital (deposits) and bank taxes. Figure 7 shows the response of the economy in both cases. The effects are similar (except for the response of pre-tax interest rates $R$, as one would expect). In both cases, the result is an increase in capital accumulation and output.

Default is a transfer from banks to the government, but so are taxes on bank's profits. However, default is a one-off transfer, while taxes on banks affect their marginal lending decisions. The positive effects of sovereign debt restructuring accompanied by a fall in taxes on banks (as compared to the counterfactual with no default) stem from these positive effects on bank credit.

The effect on investment is positive - to the point that, initially, it crowds out consumption. As time goes by, the resulting increase in capital stock leads to larger output. Labour supply does not respond significantly, so wages increase. It takes more than 4 years until consumption hits its steady-state level, but then it increases even further. Overall, in our laboratory economy, sovereign debt restructuring is better than an increase in taxes on banks' profits. 
Figure 7: Response to a change in savings taxes and bank taxes vs. lump sum taxation
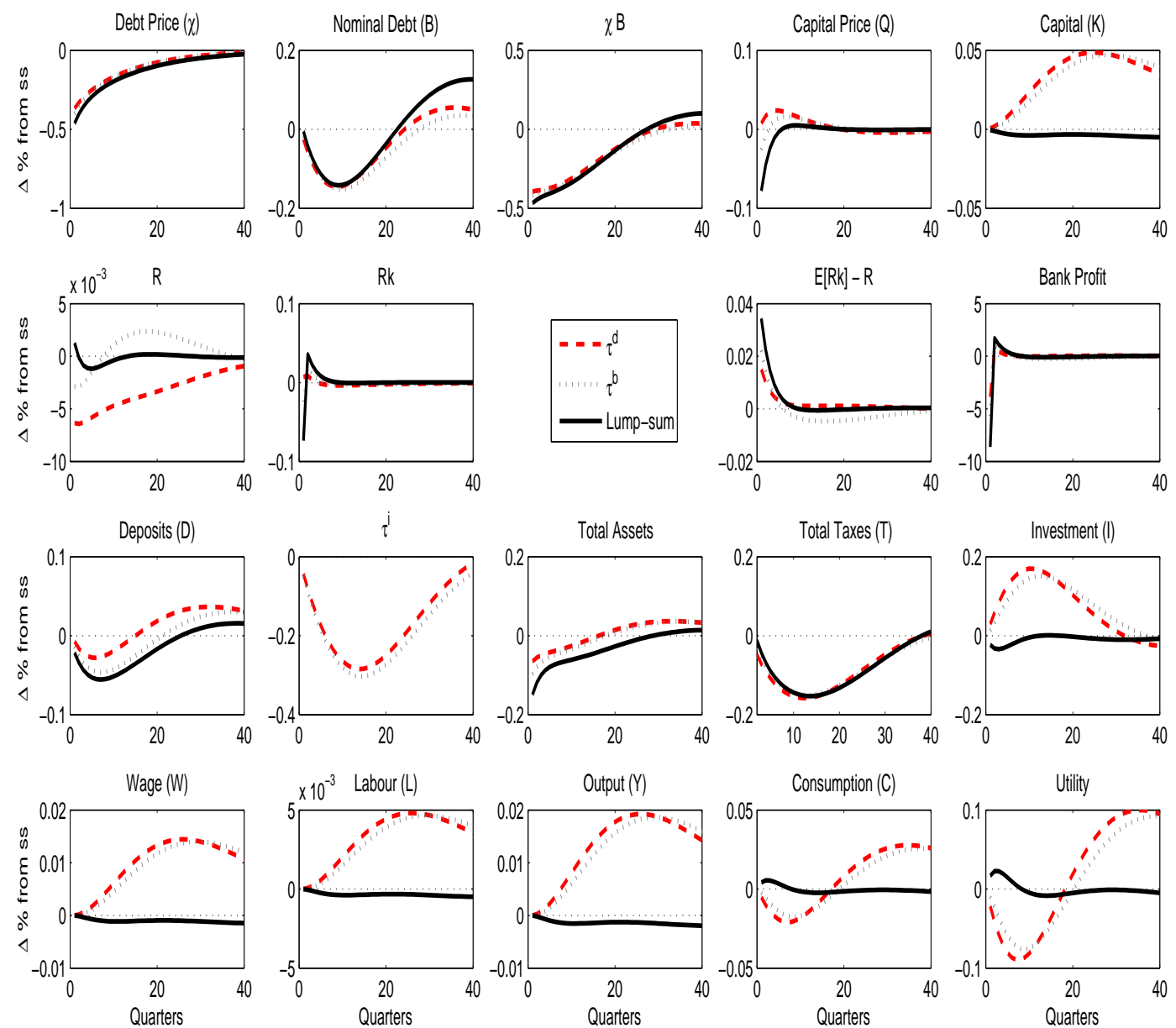

The effect of sovereign debt restructuring in place of an increase in taxes on deposits is very similar. Taxes on banks directly discourage credit, while taxes on households' deposits make their liabilities more expensive. As shown in Figure 7, the response of the economy is basically the same in both cases.

Both in this case and in case of labour taxes, the deleterious effects of sovereign default on the banking system are more than compensated by the relatively lower taxes. However, the response of the economy is different in the short and in the long run. In the short run, output and consumption react more strongly in case of labour taxes. The main reason is that the labour supply reacts quickly to changes in taxes. In the case of deposit and 
banking taxes, investment is stimulated in the short run, but since capital accumulation takes time, the output response peaks only after 5 years. In terms of their effects on the sovereign-bank loop, taxes on banks' profits and on deposits play very similar roles.

\subsubsection{The fiscal response matters}

In our laboratory economy, the fiscal reaction after a sovereign default that disrupts financial intermediation is crucial to determine whether and how diabolic the bank-sovereign loop is. On the one hand, sovereign debt restructuring in place of non-distortionary (lumpsum) taxation or non-productive government expenditures harms the economy even if no other default cost is considered. On the other hand, the financial disruption caused by a sovereign default harms the economy less than the increases in (labour or capital) income taxes that would be needed to fully serve the debt.

The benefits of a sovereign debt restruturing that avoids larger taxes on banks or on capital income appear mostly in the long run - debt restructuring reduces consumption in the first 4 years following the default. In contrast, debt restructuring in place of consumption taxes provides some short run boost to the economy but has significant negative effects in the long run.

\subsection{The speed of fiscal responses}

In the previous exercises we set the parameter $\rho_{b}$ of the fiscal response to debt restructuring so as to match in all cases a decrease in total taxes of $2.4 \%$ (compared to a counterfactual scenario with no default). In this section we let fiscal policy react to a greater extent to the default with a faster decrease in taxes. Debt recovers faster than in the baseline case and is back to its steady state level in less than seven years. We analyse the cases of lump sum, labour and deposit taxes.

In the case analyzed in Section 4.1.1, debt restructuring coupled with a relief in lump sum taxes gives rise to a very mild recession. Here, we observe that larger falls in taxes on impact give rise to a more pronounced fall in economic activity. In case taxes respond so quickly that the value of outstanding debt $\chi B$ is back to its steady state level in around two years, the fall in capital is large and leads to an output drop that reaches $0.6 \%$ (with a similar effect on wages). Intuitively, the fall in taxes is partly compensated by government debt issuance. Leverage-constrained banks have thus less room for buying firms' assets. Hence, owing to its effects on banks balance sheets, sovereign debt crowds out capital accumulation. 
Figure 8 considers the case of changes in lump-sum taxes and compares the response of the economy when the parameter $\rho_{b}$ of the fiscal rule is, respectively, two and four times higher.

Figure 8: Response to a change in lump-sum taxes: effect of speed
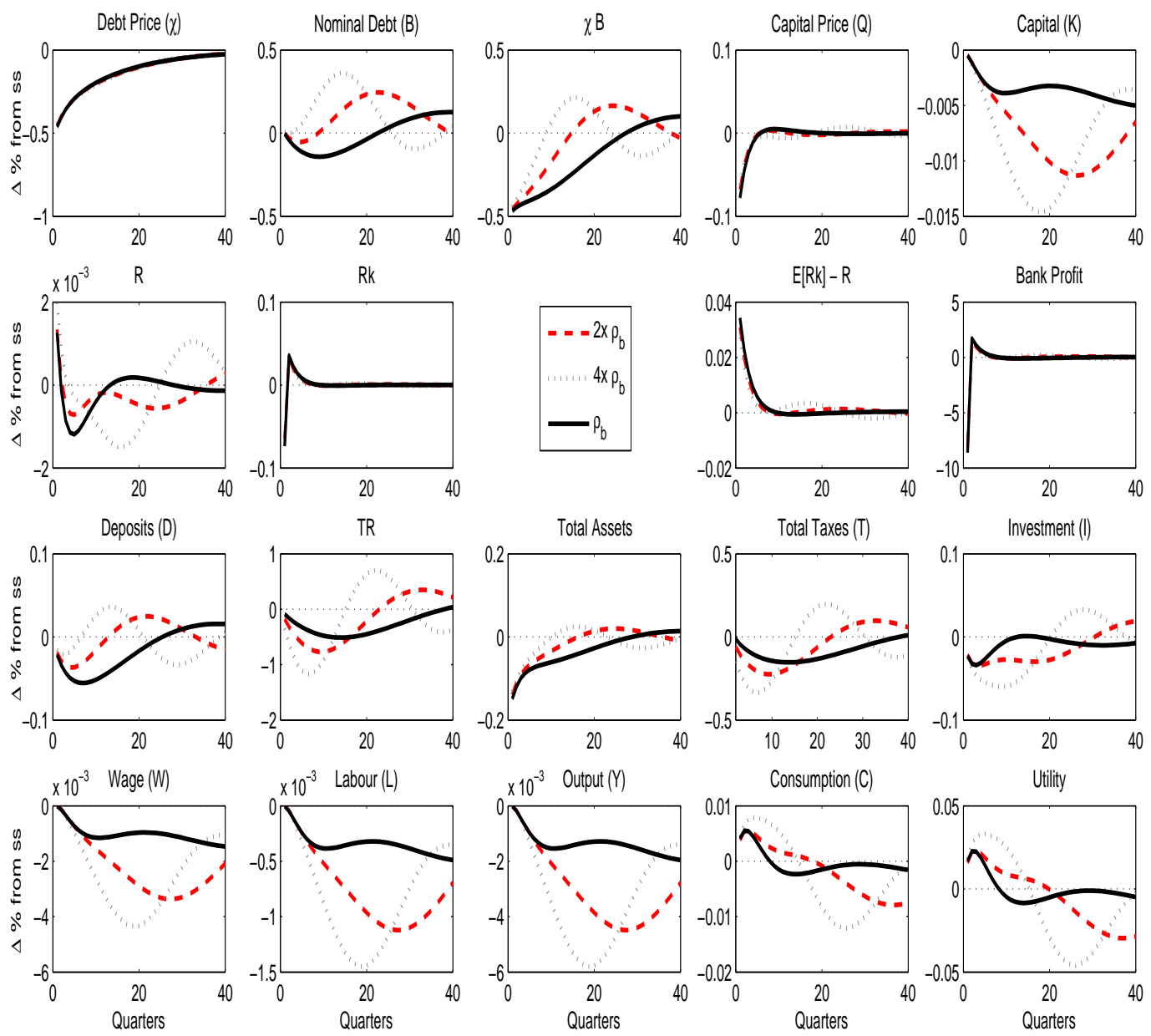

In the short run, there is a consumption boost because agents have more disposable income but investment cannot grow owing to the constraints on banks. The overall effect is however negative. Table 4 shows that the cumulated negative effect on output of a sovereign restructuring coupled with a relief in lump sum taxes is not so small if $\rho_{b}$ is large. It compares the present value percentage drop in output due to the shock 
relatively to remaining in steady state. The table shows that annualized loss of output almost doubles when the speed of adjustment is four times larger.

Table 4: Present Value of Output deviations, varying the speed of adjustment (accumulated up to 15 years, annualized)

\begin{tabular}{cccc}
\hline & $\rho_{b}$ & $2 \rho_{b}$ & $4 \rho_{b}$ \\
\hline Output & $-1.3 \%$ & $-2.1 \%$ & $-2.5 \%$ \\
\hline
\end{tabular}

Figure 8 also makes clear that different speeds of adjustment generate responses that are not a simply scaled version of one another. In particular, they have different implications in the short and in the long run. The deeper the initial fall in taxes following debt restructuring, the faster nominal debt starts to grow and the largest is the crowding out effect of sovereign debt issuance on capital accumulation.

Figure 9 shows a similar comparison for labour taxes. In this case, there is a clear trade-off between short-run and long-run effects. In the short run, a more responsive fiscal rule further stimulates labour supply and output, contributing to alleviate the financial disruption and increase investment. Nevertheless, the subsequent faster increase in nominal debt makes tax cuts short-lived and in the medium run taxes start to increase, discouraging labour supply and generating a downward movement in the economic cycle. From the perspective of the financial disruption following default, the short run recovery of asset value is faster, both because real debt value increases via nominal debt and because investment grows since firms are expanding. But this recovery is also not long-lasting and is different in its composition: asset value recovers mainly because banks buy more debt at a lower price. In contrast, in the baseline case, the stimulus provided is smooth but prolongued, and capital recovery is more pronounced in the long run. This is due to little crowding out effect of sovereign debt on capital accumulation - debt remains low for a longer time. Moreover, a very responsive fiscal stance is more likely to generate cycles, whereas a more contained rule avoids volatility and the economy returns to steady state after a shorter horizon.

Figure 10 shows a similar exercise letting deposit taxes respond. The crowding-out effect here is very important. In the baseline case, the response of output, capital and labour is very strong. The effect on output and capital in the other two cases is always weaker, if not negative, no matter the horizon. This happens precisely because faster debt increase after the restructuring crowds out capital recovery, owing to the leverage constraints faced 
Figure 9: Response to a change in labour taxes: effect of speed
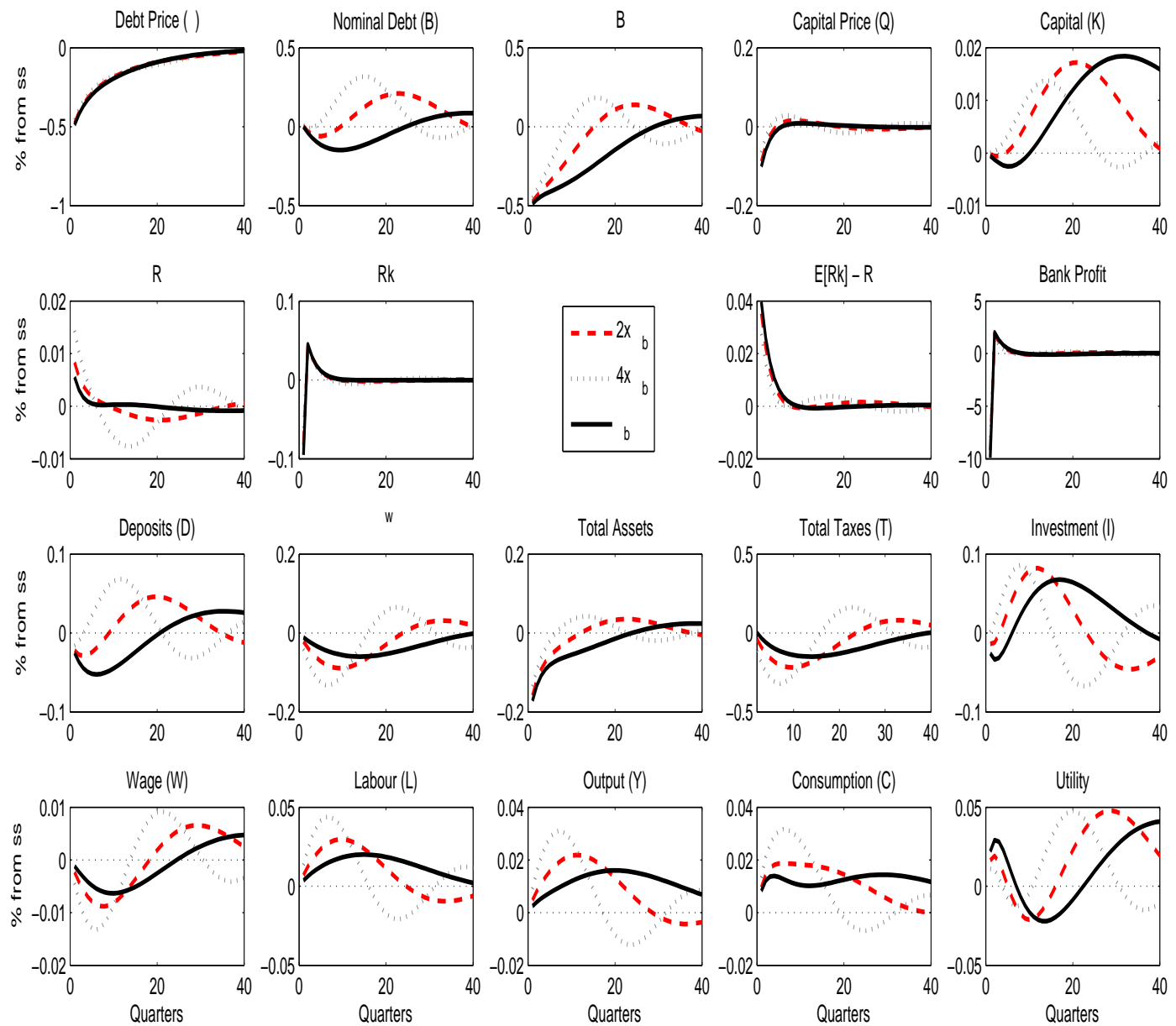

by banks. The difference between this and the exercise with labour taxes is that in the latter case, the labour response to tax cuts stimulates firms' demand for capital, which leads to more investment and attenuates the crowding out effect.

In sum, this section shows that if policy is too responsive, the crowding out effect inhibits accumulation of capital assets. In the short run, the effect depends on the tax that responds to debt fluctuations, but in the long run, a smoother fiscal stance is better. 
Figure 10: Response to a change in deposit taxes: effect of speed
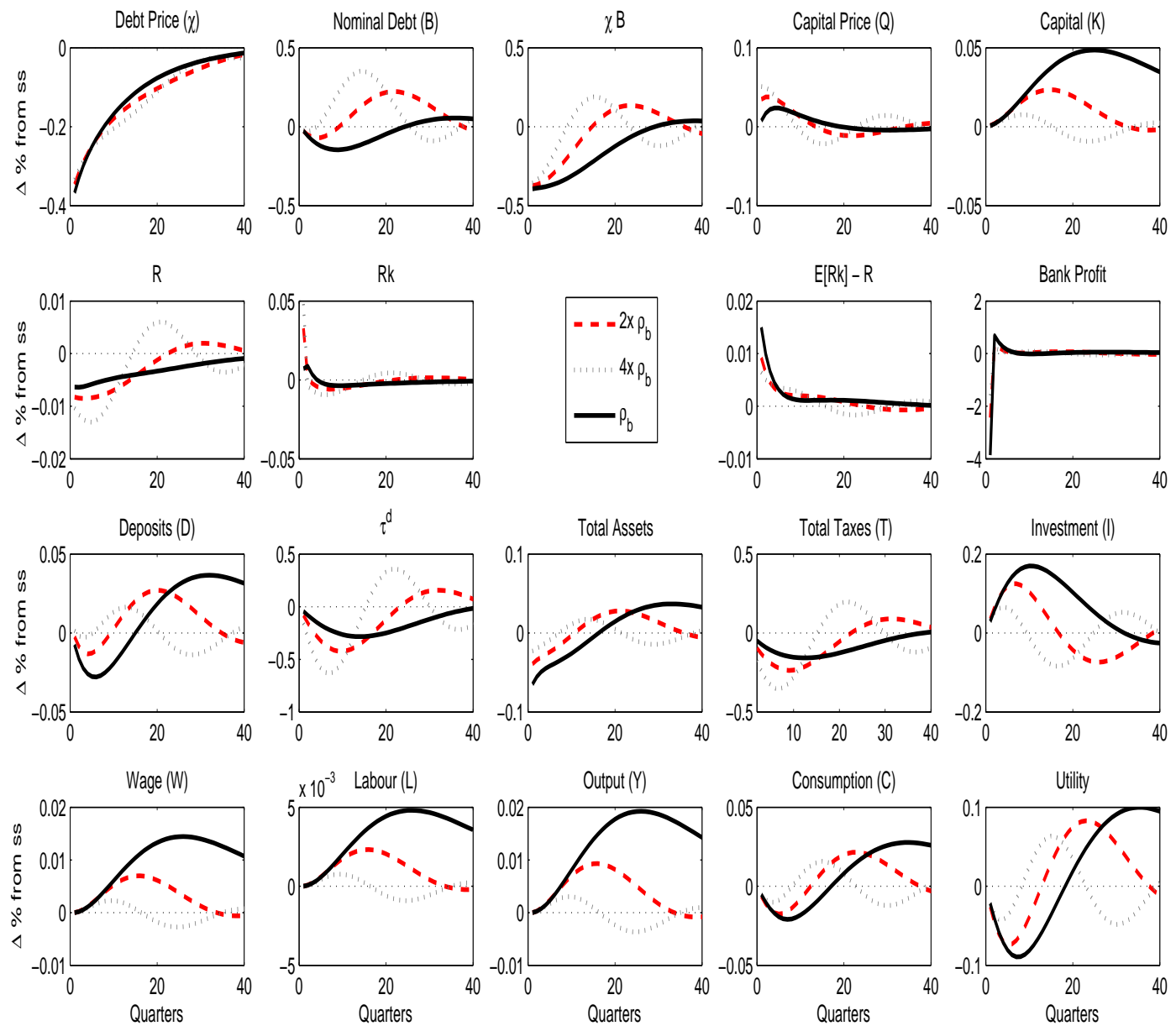

\section{$5 \quad$ Final Remarks}

We presented a simple model that captures the sovereign-bank loop and calibrated it to the Greek economy in the quarters surrounding the 2012 Bond Exchange. Our contribution is to study how rules targeting different tax instruments and speeds of fiscal reaction shape the response of this laboratory economy to a debt restructuring shock.

Sovereign default forces leveraged-constrained banks to deleverage, which has a negative impact on investment and output. As it turns out, different fiscal policy responses interact with this deleveraging effect in different ways: increasing government consumption crowds out investment, which prevents the economy from recovering in the medium 
run; lower labour taxes (compared to a counterfactual scenario with no debt restructuring and larger taxation needs) raise the marginal productivity of capital and the demand for investment, which more than offsets the losses from financial disruption; lower consumption taxes also raise the labour supply in the short run, but the stimulus for consumption crowds out investment and hence hurt the economy in the medium run; lower taxes on banks offset the effect of default and also affect marginal lending decisions, so the effect on investment is positive; lower taxes on deposits affect the economy in a very similar way by reducing the costs of funds for investment; and a more conservative fiscal stance (lower speed of adjustment) leads to a quicker recovery since government debt crowds out space for capital investment in banks' balance sheets. Thus how diabolic the post-default sovereign-bank loop is depends to a great extent on the way fiscal policy responds.

\section{References}

[1] Acharya, V., Drechsler, I. and Schnabl, P (2015). A Pyrrhic Victory? - Bank Bailouts and Sovereign Credit Risk. Journal of Finance 69, 2689-2739.

[2] Andritzky, J., (2012). Government Bonds and their Investors: What are the facts and do they matter?. IMF Working Paper 158.

[3] Bank for International Settlements, (2011). The impact of sovereign credit risk on bank funding conditions. CFGS Papers 43.

[4] Benjamin, D. and Wright, M. (2009). Recovery before Redemption: A Theory of Delays in Sovereign Debt Renegotiations. CAMA Working Papers 2009-15, Centre for Applied Macroeconomic Analysis, Crawford School of Public Policy, The Australian National University.

[5] Bernanke, B. and Gertler, M., (1989). Agency Costs, Net Worth, and Business Fluctuations. American Economic Review 79, 14-31.

[6] Bernanke, B., Gertler, M. and Gilchrist, S., (1999). The Financial Accelerator in a quantitative Business Cycle Framework. In: J. B. Taylor and M. Woodford (ed.), Handbook of Macroeconomics, edition 1, volume 1, chapter 21, 1341-1393 Elsevier.

[7] Bocola, L., (2016). The Pass-Through of Sovereign Risk. Journal of Political Economy $124,879-926$.

[8] Boissay, F., Collard, F. and Smets, F., (2016). Booms and systemic banking crises. Journal of Political Economy 124, 489-538. 
[9] Bolton, P. and Jeanne, O., (2011). Sovereign default risk in financially integrated economies. IMF Economic Review 59, 162-194.

[10] Borensztein, E. and Panizza, U., (2008). The Costs of Sovereign Default. IMF Working Papers 238.

[11] Broner, F. and Ventura, J., (2011). Globalization and Risk Sharing. Review of Economic Studies 78, 49-82.

[12] Broner, F., Erce, A., Martin, A., and Ventura, J., (2014). Sovereign debt markets in turbulent times: Creditor discrimination and crowding-out effects. Journal of Monetary Economics 61, 114-142.

[13] Brunnermeier, M., Garicano, L., Lane, P., Pagano, M., Reis, R., Santos, T., Thesmar, D., Van Nieuwerburgh, S., and Vayanos, D., (2016). The Sovereign-Bank Diabolic Loop and ESBies. American Economic Review 106(5), 508-512.

[14] Brunnermeier, M., Langfield, S., Pagano, M., Reis, R., Van Nieuwerburgh, S., and Vayanos, D., (2017). ESBies: Safety in the Tranches. Economic Policy, forthcoming.

[15] Brutti, F., (2011). Sovereign defaults and liquidity crises. Journal of International Economics 84, 65-72.

[16] Bulow, J. and Rogoff, K., (1989). Sovereign Debt: Is to forgive to forget?. American Economic Review 79, 43-50.

[17] Carlstrom, C. and Fuerst, T., (1997). Agency Costs, Net Worth, and Business Fluctuations: A Computable General Equilibrium Analysis. American Economic Review 87, 893-910.

[18] Correia, I., De Fiore, F., Teles, P. and Tristani, O., (2015). Credit Subsidies. Working Paper.

[19] Corsetti, G., Kuester, K., Meier, A. and Mueller, G., (2013). Sovereign risk, fiscal policy and macroeconomic stability. Economic Journal 123, 99-132.

[20] Corsetti, G., Kuester, K., Meier, A. and Mueller, G., (2014). Sovereign risk and belief-driven fluctuations in the Euro Area. Journal of Monetary Economics 61, 53-73.

[21] Curdia, V. and Woodford, M., (2016). Credit Frictions and Optimal Monetary Policy. Journal of Monetary Economics 84, 3065. 
[22] De Bruyckere, V., Gerhardt, M., Schepens, G. and Vennet, R., (2013). Bank/Sovereign Risk Spillovers in the European Debt Crisis. Journal of Banking and Finance 37, 47934809.

[23] Dedola, L., Karadi, P. and Lombardo, G., (2013). Global implications of national unconventional policies. Journal of Monetary Economics 60, 66-85.

[24] Eaton, J. and Gersovitz, M., (1981). Debt with Potential Repudiation: Theoretical and Empirical Analysis. Review of Economic Studies 48, 289-309.

[25] Gennaioli, N., Martin, A. and Rossi, S., (2013). Banks, Government Bonds, and Default: What do the data say?. Economics Working Papers 1378, Department of Economics and Business, Universitat Pompeu Fabra.

[26] Gertler, M. and Karadi, P., (2011). A model of unconventional monetary policy. Journal of Monetary Economics 58, 17-34.

[27] Gertler, M. and Karadi, P., (2013). QE 1 vs. 2 vs. 3...: A Framework for Analysing Large-Scale Asset Purchases as a Monetary Policy Tool. International Journal of Central Banking 9, S1.

[28] Gertler, M. and Kiyotaki, N., (2010). Financial Intermediation and Credit Policy in Business Cycle Analysis. in B. Friedman and M. Woodford (ed.), Handbook of Monetary Economics, edition 1, volume 3.

[29] Gertler, M., Kiyotaki, N. and Queralto, A., (2012). Financial Crises, Bank Risk Exposure and Government Financial Policy. Journal of Monetary Economics 59, 1434.

[30] Greenwood, J., Hercowitz, Z. and Huffman, G., (1988). Investment, Capacity Utilization and the Business Cycle. American Economic Review 78, 402-417.

[31] Guerrieri, L., Iacoviello, M. and Minetti, R., (2012). Banks, sovereign debt and the international transmission of business cycles. NBER International Seminar on Macroeconomics (ISOM) 2012, 181-213.

[32] King, R., Plosser, C., and Rebelo, S., (1988). Production, Growth and Business Cycles: I. The Basic Neoclassical Model. Journal of Monetary Economics 21, 195-232.

[33] Kiyotaki, N. and Moore, J., (1997). Credit Cycles. Journal of Political Economy 105, 211-248. 
[34] Kirchner, M. and Van Wijnbergen, S. (2016). Fiscal deficits, financial fragility, and the efectiveness of government policies. Journal of Monetary Economics 80, 51-68.

[35] Meeks, R., Nelson, B. and Alessandri, P., (2016). Shadow banks and macroeconomic instability. Journal of Money, Credit and Banking, forthcoming.

[36] Panizza, U., Sturzenegger, F., and Zettelmeyer, J., (2009). The Economics and Law of Sovereign Debt and Default. Journal of Economic Literature 47, 651-698.

[37] Perez, D., (2015). Sovereign Debt, Domestic Banks and the Provision of Public Liquidity. mimeo.

[38] Popov, A., and Van Horen, N., (2014). Exporting Sovereign Stress: Evidence from Syndicated Bank Lending during the Euro Area Sovereign Debt Crisis. Review of Finance 19, 1825-1866.

[39] Rannenberg, A., (2016). Bank leverage cycles and the external finance premium. Journal of Money, Credit and Banking, forthcoming.

[40] Sosa-Padilla, C., (2014). Sovereign Default and Banking Crises. mimeo.

[41] Trabant, M., and Uhlig, H., (2011). The Laffer curve revisited. Journal of Monetary Economics 58, 305-327.

[42] Villa, S., (2016). Financial Frictions in the Euro Area: A Bayesian Assessment. Macroeconomic Dynamics, 20, 1313-1340.

[43] Villa, S., and Yang, J., (2011). Financial intermediaries in an estimated DSGE model for the UK. In: J. Chadha and S. Holly (ed.), Interest Rates, Prices and Liquidity: Lessons from the Financial Crisis, Cambridge University Press.

[44] Wright, M., (2011). Restructuring Sovereign Debts with Private Sector Creditors: Theory and Practice. In: Primo Braga, C. and Vincelette, G. (eds.), Sovereign Debt and the Financial Crisis: Will This Time Be Different?, World Bank, pp. 295-315.

[45] Zettelmeyer, J., Trebesch, C., and Gulati, M., (2013). The Greek Debt Restructuring: An Autopsy. Economic Policy 28(75), 513-563. 


\section{A Banks allocation problem}

Using the conjecture for the value function form suggested in (22), we can write the Lagrangian for the banks' maximization problem. Banks will maximize its terminal value (18) subject to the constraint (19).

$\mathcal{L}=\nu_{t} Q_{t} K_{t+1}+\zeta_{t} \chi_{t} B_{t+1}+\eta_{t} N_{t}-\mu_{t}\left[\lambda\left(Q_{t} K_{t+1}+\chi_{t} B_{t+1}\right)-\left(\nu_{t} Q_{t} K_{t+1}+\zeta_{t} \chi_{t} B_{t+1}+\eta_{t} N_{t}\right)\right]$

That can be simplified to

$$
\mathcal{L}=\left[\nu_{t} Q_{t} K_{t+1}+\zeta_{t} \chi_{t} B_{t+1}+\eta_{t} N_{t}\right]\left(1+\mu_{t}\right)-\mu_{t} \lambda\left(Q_{t} K_{t+1}+\chi_{t} B_{t+1}\right)
$$

where $\mu_{t}$ is the Lagrangian multiplier with respect to the incentive constraint. The first order conditions for $K_{t+1}, B_{t+1}$ and $\mu_{t}$ are:

$$
\begin{gathered}
\nu_{t}\left(1+\mu_{t}\right)=\mu_{t} \lambda \\
\zeta_{t}\left(1+\mu_{t}\right)=\mu_{t} \lambda \\
\lambda\left(Q_{t} K_{t+1}+\chi_{t} B_{t+1}\right)=\nu_{t} Q_{t} K_{t+1}+\zeta_{t} \chi_{t} B_{t+1}+\eta_{t} N_{t}
\end{gathered}
$$

The first and second FOCs are symmetric. On the left hand side is the marginal benefit for the bank from expanding each of the assets components and on the right hand side the marginal cost of tightening the incentive constraint by $\lambda$. The last FOC is the incentive constraint itself.

The constraint binds $\left(\mu_{t}>0\right)$ only if the marginal discounted value of both the banks assets is positive. In case the constraint binds, the FOCs for securities and bonds show that the discounted marginal value for each of those components should be equal. It means that in the margin, the bank is indifferent from investing resources in government bonds or private securities.

Now we show that the conjectured form of the value function holds. From (20), (21) and (22) we have:

$\nu_{t} Q_{t} K_{t+1}+\zeta_{t} \chi_{t} B_{t+1}+\eta_{t} N_{t}=E_{t} \beta \Lambda_{t, t+1}\left\{(1-\theta) N_{t+1}+\theta\left[\nu_{t+1} Q_{t+1} K_{t+2}+\zeta_{t+1} \chi_{t+1} B_{t+2}+\eta_{t+1} N_{t+1}\right]\right\}$

Using the definitions of $\varpi_{t}$ and $\phi_{t}$, we simplify the above equation to:

$$
L H S=E_{t} \beta \Lambda_{t, t+1}\left\{(1-\theta) N_{t+1}+\theta N_{t+1}\left[\nu_{t+1} \varpi_{t+1}+\zeta_{t+1}\left(\phi_{t+1}-\varpi_{t+1}\right)+\eta_{t+1}\right]\right\}
$$


Inserting the definition of $\tilde{\Omega}_{t}$ we get:

$$
L H S=E_{t} \beta \Lambda_{t, t+1} \tilde{\Omega}_{t+1} N_{t+1}
$$

Substituting for $N_{t+1}$ :

$L H S=E_{t} \beta \Lambda_{t, t+1} \Omega_{t+1}$

$$
\cdot\left[\left(r_{t+1}^{k}-r_{t+1}\right) Q_{t} K_{t+1}\left(1-\tau_{t+1}^{b}\right)+\left(r_{t+1}^{b}-r_{t+1}\right) \chi_{t} B_{t+1}\left(1-\tau_{t+1}^{b}\right)+\left(1+r_{t+1}\left(1-\tau_{t+1}^{b}\right)\right) N_{t}\right]
$$

Comparing the terms for $K_{t+1}, B_{t+1}$ and $N_{t}$, we see that the conjecture holds if (24), (25) and (23) hold.

\section{B Data}

\begin{tabular}{|c|c|c|}
\hline Variable & Source & Description \\
\hline Private Consumption & $\mathrm{E}$ & Final Consumption Expenditure of Households \\
\hline Fixed Capital Formation & $\mathrm{E}$ & Gross Fixed Capital Formation \\
\hline Government Consumption & $\mathrm{E}$ & Final Consumption Expenditure of General Government \\
\hline Debt & $\mathrm{E}, \mathrm{BG}$ & Loans and Securities from Domestic General Government \\
\hline Interest Payments & $\mathrm{E}$ & Interest, payable \\
\hline Term to Maturity & $\mathrm{B}$ & Average Residual Maturity \\
\hline Leverage & BS & Average (inverse of Tier1 Ratio and total capital ratio) \\
\hline Assets & BG & Claims on Domestic Entities \\
\hline Net Worth & BG & Capital and Reserves (Greek Commercial Banks, Consolidated) \\
\hline Banks' Profits & BG & Profit Before Tax (Greek Commercial Banks, Consolidated) \\
\hline Deposits & BG & Deposits to Domestic Credit Institutions (by households) \\
\hline Interest paid on Deposits (rD) & BG & Interest Expense (Greek Commercial Banks, Consolidated) \\
\hline Total Wages (WL) & $\mathrm{E}$ & Wages and Salaries \\
\hline Taxes & $\mathrm{E}$ & Total Tax Receipts \\
\hline Income Tax & $\mathrm{E}$ & Taxes on Individual or Household Income \\
\hline Wage Taxes & $\mathrm{E}$ & Income Taxes * WL / (rD + WL) \\
\hline Deposit Taxes & $\mathrm{E}$ & Income Taxes * rD / (rD + WL) \\
\hline Consumption Taxes & $\mathrm{E}$ & Value Added Type Taxes, Excise Duties and Consumption Taxes \\
\hline Bank Taxes & $\mathrm{E}$ & Current Taxes on Capital \\
\hline
\end{tabular}

Table 5: Data Sources and Description

E: Eurostat, BG: Bank of Greece, B: Bloomberg, BS: Bankscope 


\section{Sensitivity analysis}

\section{C.1 Persistence of tax rule $\left(\rho_{x}\right)$}

The baseline tax rule has an autoregressive component $\rho_{x}$ calibrated to 0.9 in the baseline exercises. We now compare the response of labour taxes setting this parameter to 0.8. Figure 11 (appendix) displays results and shows that the effect of a less persistent tax rule is similar to the one of less responsive fiscal rule in terms of comparison between short and long run response. However there is not a very noticeable difference in terms of cycles generated in the economy.

Figure 11: Response to a change in labour taxes: effect of rule persistence
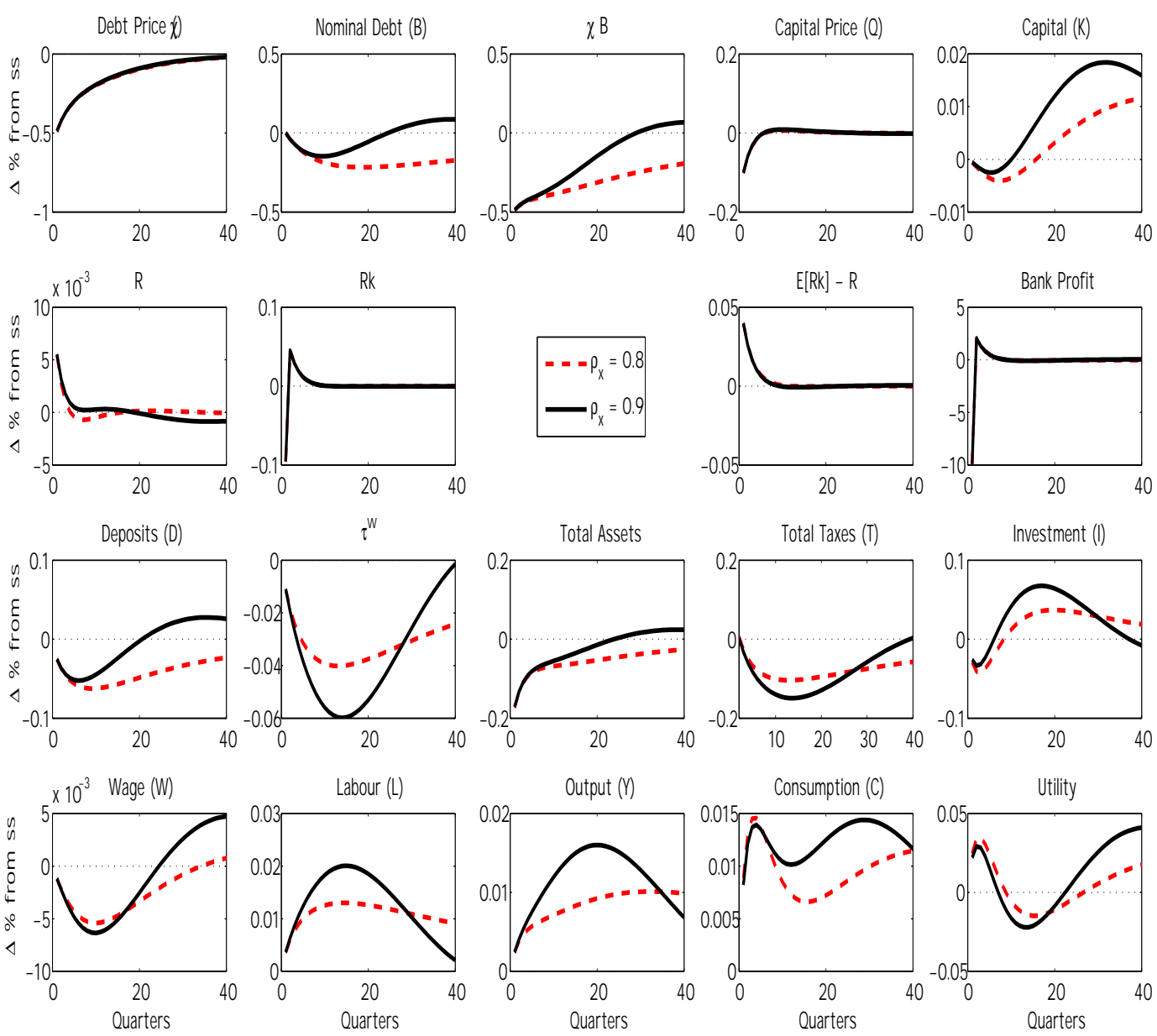


\section{C.2 Changing preferences}

Our model assumes households have GHH-type preferences, which have the particular feature of generating a labour supply that depends only on the real wage. This formulation hence shuts down the wealth effect on the labour supply.

In order to guarantee that our (qualitative) results are not attached to the particular form of utility function used, we simulate the model alternatively using KPR-type preferences, following King, Plosser and Rebelo (1988):

$$
u(C, L)=\ln C_{t}-\psi \frac{L_{t}^{1+\varphi}}{1+\varphi}
$$

This specification makes utility separable in consumption and labour. Labour supply choice will not be independent from consumption and wealth effects are present. The first order conditions change to:

$$
\begin{gathered}
\psi L_{t}^{\varphi}=\frac{\left(1-\tau_{t}^{w}\right) W_{t}}{\left(1+\tau_{t}^{c}\right) C_{t}} \\
\Lambda_{t, t+1} \equiv \frac{C_{t}}{C_{t+1}} \frac{\left(1+\tau_{t}^{c}\right)}{\left(1+\tau_{t+1}^{c}\right)}
\end{gathered}
$$

Figures 12 and 13 (in appendix) address the exercises with labour and capital taxes for this type of preferences. Qualitatively results do not seem to change much. The key difference in both cases lies in the labour response and generates a small quantitative difference for the utility path.

For the case of labour taxes the KPR preferences make labour react less to the fiscal rule, for the same cut in taxes. This milder reaction also causes investment no to increase as much as for GHH preferences, and so GDP and consumption increase less. This is exactly due to the wealth effect from equation (35): an increase in real wage also increases consumption, so that labour responds less to a similar increase in net wage. Output increases around 1/3 less, due to smaller labour and capital reaction.

The case of deposit taxes is distinct in that labour supply reacts more in the short run. The decrease in capital taxes stimulates savings at the expense of consumption, as in the GHH case. But with KPR preferences, this implies an immediate increase in labour supply. In the long run labour supply falls as consumption starts to increase following output expansion. Quantitatively the effect on output and utility, as well as the size of the effects on banks and the fiscal side, are very close. 
Figure 12: Response to a change in labour taxes: GHH vs. KPR utility function
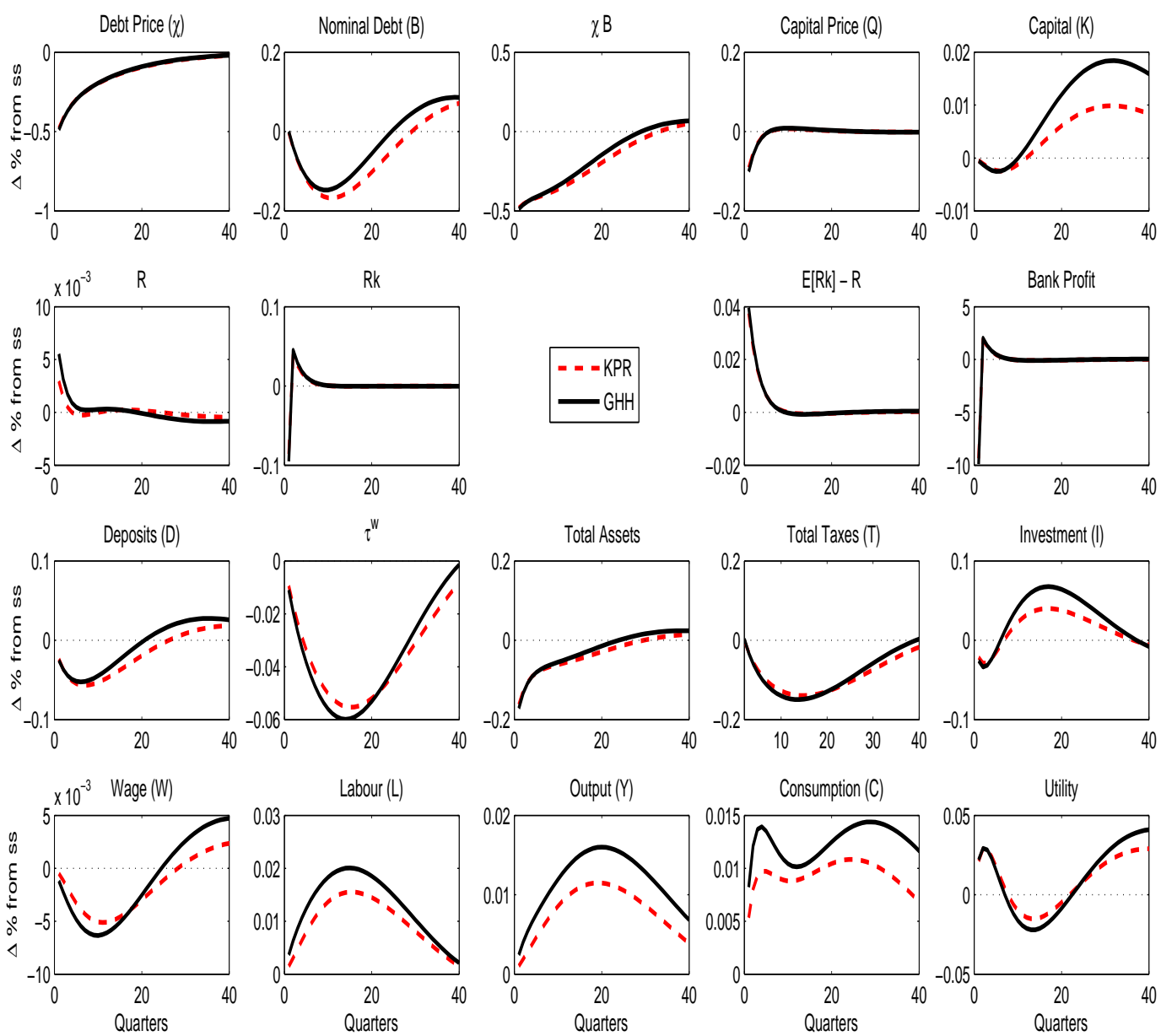

Reaction for consumption and bank taxes (available upon request) follow, respectively, the qualitative response of labour and deposit taxes. This subsection clarifies thus that the qualitative effects discussed above do not lie on the assumption about the utility funcion neither do much the quantitative ones. 
Figure 13: Response to a change in deposit taxes: GHH vs. KPR utility function
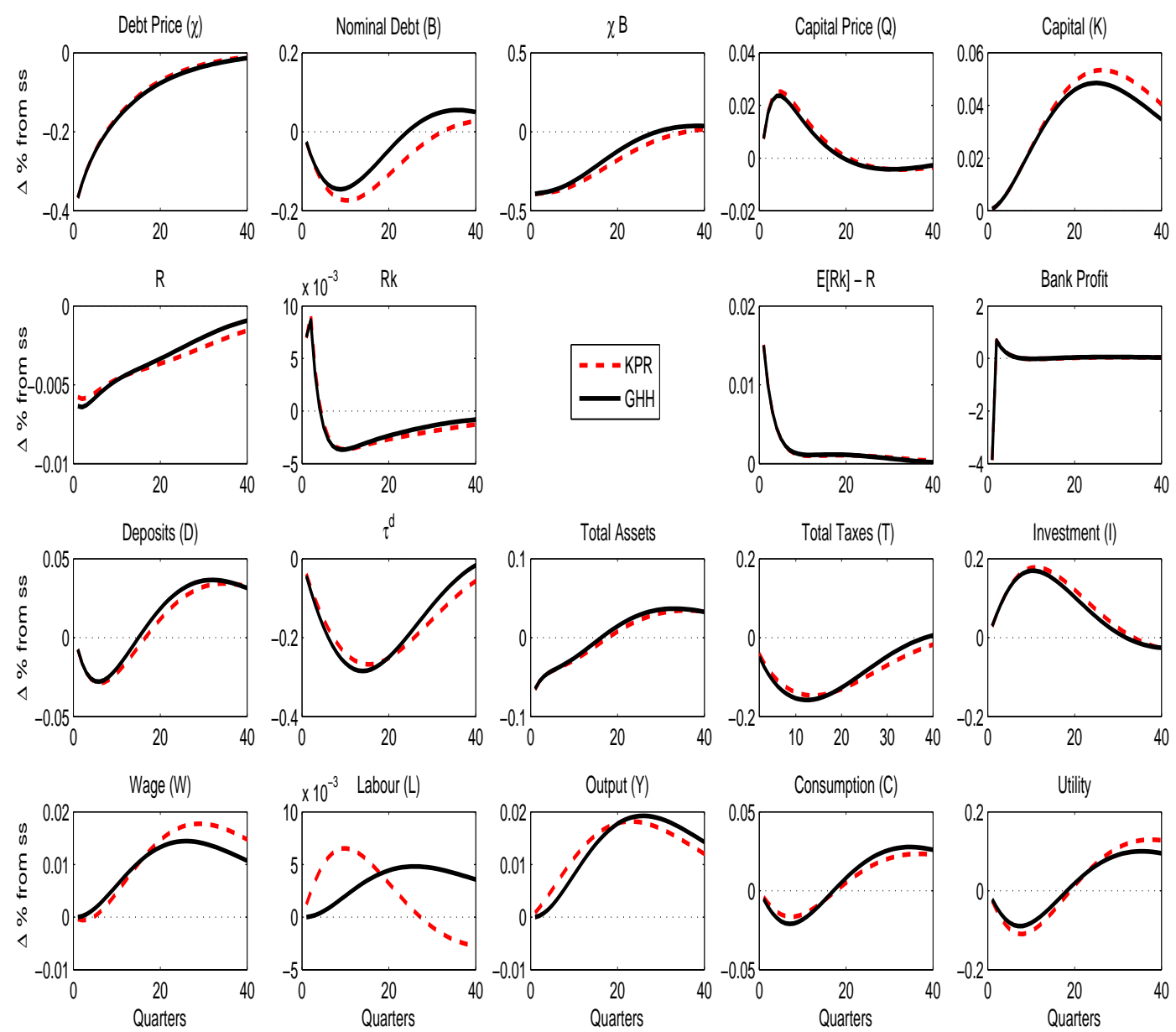